Price Determinants of Sharing Economy Based Accommodation Rental:

A Study of Listings from 33 Cities on Airbnb.com

\author{
Dan Wang* \\ School of Hotel and Tourism Management \\ The Hong Kong Polytechnic University \\ 17 Science Museum Road \\ TST East, Kowloon, Hong Kong \\ Tel.: +852 3400 2282; fax: +852 23629362 \\ E-mail: d.wang@polyu.edu.hk
}

\author{
Juan L. Nicolau \\ Department of Marketing \\ Faculty of Economics \\ University of Alicante \\ PO Box 99, 03080 Alicante, Spain \\ Tel. and fax: +34965903621 \\ E-mail: j1.nicolau@ua.es
}




\title{
Price Determinants of Sharing Economy Based Accommodation Rental: \\ A Study of Listings from 33 Cities on Airbnb.com
}

\begin{abstract}
The advent of the "sharing economy" challenges not only the business of hotel industry but also the theories and models based on the conventional hotel industry. A key dimension of the hospitality industry is pricing. The aim of this study is to identify the price determinants of sharing economy based accommodation offers in the digital marketplace. Specifically, a sample of 180,533 accommodation rental offers in 33 cities listed on Airbnb.com is investigated using ordinary least squares and quantile regression analysis. Thirty-one explanatory variables in five categories (host attributes, site and property attributes, amenities and services, rental rules, and online review ratings) are explored for the intricacies of the relationships between pricing and its determinants.
\end{abstract}

Keywords: Sharing economy; Price determinants; Airbnb; Hotels; Quantile regression. 


\section{Introduction}

In recent years, a new business model known as the "sharing economy" has emerged in the accommodation sector of the tourism and hospitality industry (Gansky, 2010; Sundararajan, 2013). Airbnb has pioneered the use of this business model to connect people who own idle accommodation assets (such as empty rooms or apartments) with those who need temporary accommodation (such as tourists) via digital marketplaces (Botsman \& Rogers, 2011; Zervas, Proserpio, \& Byers, 2016). The exponential growth of sharing economy based accommodation rental has been attributed to the provision of a wide range of prices and property features, as well as a more diversified experience than that of conventional hotel accommodation (Guttentag, 2013; Tussyadiah \& Pesonen, 2015; Wang et al., 2016). Recognizing the challenges and opportunities brought by the sharing economy based business model, scholars and industry practitioners have investigated the effects of sharing economy based accommodation rental on the hotel industry (Zervas, et al., 2016); on tourists' accommodation experiences and behavior (Chen, 2012; Shengkui, Shulin, \& Liao, 2013; Tussyadiah \& Zach, 2015; Zervas, Proserpio, \& Byers, 2015). Studies of the morality of such unconventional accommodation rental as a form of alternative tourism have also been conducted (Molz, 2012, 2013; Steylaerts \& Dubhghaill, 2012).

Pricing is widely acknowledged to be one of the most critical factors determining the long-term success of the accommodation industry (Hung, Shang, \& Wang, 2010). Many studies have been conducted on pricing strategies in the hospitality industry from both the demand side (Becerra, Santaló, \& Silva, 2013; Chen \& Rothschild, 2010; Espinet, Saez, Coenders, \& Fluvià, 2003; Hung et al., 2010; Lee \& Jang, 2012; Saló, Garriga, Rigall-I-Torrent, Vila, \& Fluvià, 2014; Schamel, 2012; Thrane, 2007; Yang, Mueller, \& Croes, 2016; Zhang, Zhang, Lu, Cheng, \& 
Zhang, 2011) and the supply side (Heo \& Hyun, 2015; Lee, 2011; Masiero, Nicolau, \& Law, 2015). Previous researchers have helped to improve practices in the hospitality industry by identifying the determinants of hotel-room rates, the factors influencing hotel guests' willingness to pay, and the effects of different pricing strategies on customers' perceptions and satisfaction (Hung et al., 2010). However, only a few researchers have investigated the factors determining the price of sharing economy based accommodation (Gutt \& Hermann, 2015; Li, Moreno, \& Zhang, 2015).

With the growth of a supplier community for sharing economy based accommodation rental, examination of the pricing of this unconventional accommodation offers important insights for stakeholders into the means of improving their profits and developing their business. More attention should be paid to stakeholders' interests when the contribution of the sharing economy to society is non-negligible (Heo, 2016). In addition, research on the determinants of sharing economy based accommodation pricing is important due to the limited generalizability of existing studies of hotel price determinants to the context of the sharing economy. Many price indicators used in the conventional hospitality industry, such as star ratings and corporate affiliation, are unsuited to accommodation offers in the sharing economy, of which the majority are personal assets used for residential purposes (Guttentag, 2015). Therefore, a series of new price indicators associated with sharing economy based accommodation has been identified, such as host characteristics (Gutt \& Hermann, 2015; Li et al., 2015), special amenities, and certain diversified accommodation characteristics. In addition, due to the distinctive characteristics of sharing economy accommodation services, particularly the availability of idle assets and nonprofessional business owners (Botsman \& Rogers, 2010), it is useful to reexamine the influence of determinants relevant to the conventional hospitality industry. For example, the effects of 
location on price are unclear, as the location of a sharing economy rental is not predetermined by the supplier.

The purpose of this study is to identify the price determinants of sharing economy based accommodation offers in the digital marketplace (specifically Airbnb.com). A sample of 180,533 accommodation rental offers from 33 cities listed on Airbnb.com is examined. Ordinary least squares (OLS) analysis and quantile regression $(\mathrm{QR})$ analysis are used to investigate price determinants in five categories: host attributes, site and property attributes, amenities and services, rental rules, and online review ratings. The findings have important implications for the design of pricing-suggestion systems for sharing economy based accommodation service providers, such as the price-recommendation tool recently launched by Airbnb.

\section{Literature review}

\subsection{Sharing economy based accommodation rental \& its price determinants}

The sharing economy is a socio-economic system that coordinates "the peer-to-peerbased activity of obtaining, giving, or sharing the access to goods and services" through “community-based online services" (Hamari, Sjöklint, \& Ukkonen, 2015). The sharing economy is the result of technological and socio-economic progression (Belk, 2014; Botsman \& Rogers, 2010). The rapid development of information and communication technologies, both hardware (e.g., smartphones and iPads) and software (e.g., Web 2.0 applications), has enabled users to generate their own content, share information, collaborate, and conduct transactions via online platforms/marketplaces (Kaplan \& Haenlein, 2010). Meanwhile, the economic and societal pressure caused by global economic recession has made people more careful about their 
spending (Bostman \& Rogers, 2011; Gansky, 2011). The sharing economy provides an alternative means of resource distribution and consumption (Lamberton \& Rose, 2012). Therefore, sharing economy based business models have been rapidly adopted in a variety of areas, such as the rental of owned assets (Airbnb.com for accommodation and RelayRides.com for cars), general purpose freelance labor provision (e.g., oDesk.com and Fiverr.com), and peerto-peer asset sales (e.g., Etsy.com) (Sundararajan, 2014).

Sharing economy based accommodation rental business has experienced phenomenal growth due to high tourist demand (Guttentag, 2015; Heo, 2016; Karlsson \& Dolnicar, 2016; Tussyadiah \& Pesonen, 2015). Such accommodation is made available in digital marketplaces (e.g., Airbnb.com, 9flats.com, and HomeAway.com) by individuals who own the right to use the space provided (Guttentag, 2015; Heo, 2016). The types of accommodation offered vary from private rooms to castles (Wortham, 2011). Some hosts continue to reside in their properties alongside renters; some are temporarily absent; and others run permanent rental businesses (Guttentag, 2015). Tourists report multiple benefits of sharing economy based accommodation rental, such as cost reduction (the main benefit) and the opportunity for cultural exchange and social interaction with their hosts (who may be local residents) (Balck \& Cracau, 2015; Guttentag, 2015; Quinby \& Gasdia, 2014). Airbnb.com, “a trusted community marketplace for people to list, discover, and book unique accommodation around the world" (About us - Airbnb, n.d.), is the leading platform for sharing economy based accommodation rental business. Founded in 2008 by Brian Chesky and Joe Gebbia, Airbnb.com offers more than 500,000 listings in 33,000 cities and 192 countries (CrunchBase.com, retrieved on May 11, 2016). The company made $\$ 900$ million in revenue in 2015, and has a market value of $\$ 24$ billion (Kokalitcheva, 2015). 
Most existing studies investigate social and psychological aspects of the sharing economy based accommodation phenomenon, such as the motivation of consumers (e.g., Guttentag, 2015; Möhlmann, 2015; Tussyadiah \& Pesonen, 2015) and hosts (Ert, Fleischer, \& Magen, 2016; Karlsson \& Dolnicar, 2016; Li et al., 2015; Tussyadiah, 2016). A few working papers have been written on the economic effects of sharing economy based accommodation services (Fang, Ye, \& Law, 2016; Gutt \& Hermann, 2015; Ikkala \& Lampinen, 2014; Kakar, Franco, Voelz, \& Wu, 2016; Li et al., 2015; Pairolero, 2016; Tang \& Sangani, n.d.; Zervas et al., 2015). The findings indicate that hosts who offer accommodation to rent on Airbnb.com usually charge higher prices if their accommodation has received high star ratings (Gutt \& Hermann, 2015; Ikkala \& Lampinen, 2014). Li et al. (2015) provides empirical evidence from the New York City market that professional hosts (listing multiple properties) earn significantly more than non-professional hosts (listing only one property). Tang and Sangani (n.d.) identify a relationship between location and listing price based on San Francisco Airbnb listings. Kakar et al. (2016) measure the influence of information on hosts' racial background on Airbnb listing prices in San Francisco. Pairolero (2016) explores the effects of Airbnb on the housing market of Washington DC. These studies have initiated the efforts to examine the factors determining the price of sharing economy based accommodation. However, these studies were mainly developed from the dataset from one city and with limited independent variables for a certain aspect such as host characteristics or location. Such research design constrains the understanding of the price determinants for sharing accommodation rentals. In our view, a global model that controls geographical locations and describes the price determinants in different cities over the world is more capable to reflect the market situation. Assuming that the listed prices on the Airbnb are acceptable prices in the market for tourists from all over the world, the global model reflects the association of price and 
price determinants in the state of market equilibrium. Furthermore, it can be more accurately reveal the effects of price determinants by examining the multiple determinants such as host attributes, site and property attributes, amenities and services, rental rules, and online review ratings in one model.

Though only a few studies being identified for price determinants of sharing economy based accommodation rentals, a large number of studies have been conducted for hotel price determinants, which provides a reference point to design our study and compare findings to reveal the differences of two kinds of accommodation rentals in terms of price determinants. In the following section, relevant studies of hotel price determinants are reviewed.

\subsection{Hotel price determinants}

Since the early 1990s, several studies have been conducted to identify the factors determining the price of hotel accommodation. The hotel price determinants identified fall into five categories: site-specific characteristics, quality-signaling factors, hotel services and amenities, accommodation specification, and external market factors. Table 1 summarizes the findings reported in previous studies, with details of the sample and method(s) used in each study.

\section{Insert Table 1 Here}

The most important site-specific characteristic is hotel location, which has been shown to play a key role in hotel investment (Yang, Luo, \& Law, 2014; Yang, Tang, Luo, \& Law, 2015). Hotel location is usually given in terms of distance from the city center, transportation hub, major attractions, or beach (Bull, 1994; Chen \& Rothschild, 2010; Hung et al., 2010; Lee \& 
Jang, 2012; Schamel, 2012; White \& Mulligan, 2002; Zhang et al., 2011). The findings of previous studies on the influence of hotel location on price are quite consistent: a shorter distance from a focal point such as the city center is generally correlated with a higher price.

The second category of hotel price determinants comprises quality-signaling factors, defined as "various factors that reduce the information asymmetries in the market by offering buyers information on the quality of products they intend to purchase" (Yang et al., 2016, p. 42). Researchers have identified several hotel quality signaling factors, such as star rating, online customer rating, and chain affiliation (see Table 1). Using the star-rating system, "accommodation establishments of the same type (e.g., hotels, motels and inns)" are conventionally "broken down into classes, categories, or grades according to their common physical and service characteristics and established at government, industry or other private levels" (UNWTO and IHRA, 2004, p. 9). The organizations responsible for producing ratings vary between countries (Guillet \& Law, 2010). The findings of previous studies indicate that star ratings have a significant positive influence on hotel price in both Western and Eastern countries (Becerra et al., 2013; Bull, 1994; Chen \& Rothschild, 2010; Israeli, 2002; Masiero et al., 2015; Saló et al., 2014; Schamel, 2012; Yang et al., 2016; Zhang et al., 2011). In the era of ecommerce, online customer ratings are widely acknowledged to reflect service quality and reputation (Ye, Law, \& Gu, 2009). Schamel (2012) and Yang et al. (2016) provide empirical evidence of the positive influence of high customer rating scores on hotel price. Finally, branded chain affiliation has been identified as an important hotel-quality signal. Researchers have shown empirically that hotels affiliated with branded chains usually charge higher prices (Becerra et al., 2013; Chen \& Rothschild, 2010; Lee \& Jang, 2012; Thrane, 2007; White \& Mulligan, 2002; Yang et al., 2016). However, in some regions, such as Taipei, Taiwan and Israel, the effect of 
branded chain affiliation on hotel price is insignificant or unclear (Hung et al., 2010; Israeli, 2002).

The third category of hotel price determinants comprises hotel amenities and services. Variables related to amenities and services have been enumerated in several hotel price determinant models (Becerra et al., 2013; Chen \& Rothschild, 2010; Israeli, 2002; Masiero et al., 2015; Saló et al., 2014; Schamel, 2012; Yang et al., 2016; Zhang et al., 2011). Hotel rates are usually higher if amenities such as mini-bars, televisions, safes, and hair dryers are provided (Lee \& Jang, 2012; Schamel, 2012; Thrane, 2007). Hotels providing laundry services usually charge lower prices (Lee \& Jang, 2012). Higher room rates may be also associated with the provision of services such as express checkout, breakfast, and advance booking, and with a high ratio of housekeepers to guests (Masiero et al., 2015; Schamel, 2012; Yang et al., 2016). Inconsistent findings have been obtained for Internet access. In studies conducted before 2010, the provision of Internet access was reported to be positively associated with hotel price (Chen \& Rothschild, 2010). However, this effect has been negative since 2010 due to the ubiquity of Internet services and the rise of economical hotels (Schamel, 2012; Yang et al., 2016).

The fourth category of hotel price determinants comprises property characteristics, such as number of rooms, age of building, and presence of a business center, bar, car park, fitness center, and swimming pool (Becerra et al., 2013; Chen \& Rothschild, 2010; Espinet et al., 2003; Hung et al., 2010; Lee \& Jang, 2012; Saló et al., 2014; Schamel, 2012; Thrane, 2007; Yang et al., 2016; Zhang et al., 2011). However, only the presence of car parks (Espinet et al., 2003; Lee \& Jang, 2012; Saló et al., 2014; Thrane, 2007) and fitness centers (Chen \& Rothschild, 2010; Yang et al., 2016) has been consistently found to be associated with higher room rates. The 
effects of other property characteristics remain unclear, due to the inconsistent findings of previous studies.

The last category of hotel price determinants comprises market and industry characteristics. For instance, the number and proximity of competitors have been shown to influence hotel price (Balaguer \& Pernías, 2013; Becerra et al., 2013). Low market accessibility, indicated by high flight costs, is also associated with low hotel prices (Yang et al., 2016). In addition, studies have been conducted from a demand perspective to identify hotel price determinants related to guests' willingness to pay (Heo \& Hyun, 2015; Lee, 2011; Masiero et al., 2015).

There are only a few studies on the price determinants of the non-hotel accommodation offers (Monty \& Skidmore, 2003; Portolan, 2013). Monty and Skidmore (2003) applied the hedonic price model to evaluate the price determinants of bed and breakfast amenities, and identified the positive effects of a hot tub, a private bath, and a larger room on room price. Portolan (2013) also applied hedonic price model to examine the impact of private tourist accommodation facilities on prices, and identified that the availability of free parking place and sea view can be associated with a higher room rate. Both of the above studies identified the important influence of location.

\section{Methodology}

3.1. Variables and data 
Based on the previous literature on sharing economy based accommodation rentals and hotel price determinants, the effects of 25 variables in the following 5 categories are examined: host attributes, site and property attributes, amenities and services, rental rules, and online review ratings. These variables are listed and defined in Table 2. With an average price of US $\$ 117.18$, the main characteristics of the sample are as follows: only $9 \%$ of hosts are "superhosts"; "entire home/apartment" is the prevalent room type in the sample (65\%), followed by "private room" (32\%); $94 \%$ have wireless internet; only $9 \%$ offers breakfast and $16 \%$ instant booking; only $4 \%$ and $6 \%$ require guest's profile picture and phone verification respectively; and the average review score for overall rating is 92.08 .

\section{Insert Table 2 Here}

The sampled Airbnb listings from 33 cities and the corresponding variable information are drawn from a third-party website, Insideairbnb.com (n.d.), which provides data sourced from information publicly available on Airbnb.com. In Table 3, all of the details on the listings for each city are provided. As some accommodation is listed but not linked with actual transactions, we use only listings with at least one online customer review to ensure that the price of the accommodation listed reflects the market equilibrium to some degree. Ye et al. (2009) confirm the association of online review ratings with hotel-room sales, indicating that reviews suggest real transactions. A sample of 180,533 accommodation rental offers listed on Airbnb.com is analyzed.

\section{Insert Table 3 Here}

\subsection{Data analysis}

Linear QR models and linear OLS regression models are used to detect linear relationships between a dependent variable and a set of explanatory variables. The main difference between the model types is that OLS regression models are based on the conditional mean of the dependent 
variable, whereas QR models are based on the conditional $\tau$ th quantile of the dependent variable, where $\tau \in(0,1)$. Therefore, QR goes beyond the analysis of the conditional mean of a dependent variable, providing a more comprehensive description of the conditional distribution. In other words, rather than estimating the average response of the dependent variable to changes in the explanatory variables, QR measures the effects of individual explanatory variables on the whole distribution of the dependent variable. This allows the analyst to uncover hidden price-response patterns that exist depending on the level of prices.

QR is specified as follows (Koenker \& Bassett, 1978). Assuming a random variable $Y$ with a probability-distribution function $F(y)=\operatorname{Prob}(Y \leq y)$, the $\tau$ th quantile of $Y$ can be defined as the smallest value of $y$ satisfying $F(y) \geq \tau: Q(\tau)=\inf \{y: F(y) \geq \tau\}$, where $0<\tau<1$.

For $n$ observations of $Y$, the empirical distribution function is given as $F_{n}(y)=\sum 1\left(Y_{i} \leq y\right)$, where $1(z)$ is an indicator function that takes the value of 1 if the argument $z$ is true and 0 otherwise. Accordingly, the empirical quantile is defined as follows:

$$
Q_{n}(\tau)=\inf \{y: F(y) \geq \tau\}
$$

This expression is given as an optimization problem below:

$$
Q_{n}(\tau)=\arg \min _{\xi}\left\{\sum_{i: Y_{i} \geq \xi} \tau\left|Y_{i}-\xi\right|+\sum_{i: Y_{i}<\xi}(1-\tau)\left|Y_{i}-\xi\right|\right\}=\arg \min _{\xi}\left\{\sum_{i} \rho_{\tau}\left|Y_{i}-\xi\right|\right\},
$$

where $r_{t}(u)=u(\tau-1(u<0))$ is the so-called check function, which weights positive and negative values asymmetrically. A linear specification of the conditional quantile of the dependent variable gives $Q\left(\tau \mid X_{i}, \beta(\tau)\right)=X_{i}^{\prime} \beta(\tau)$, where $X_{i}$ is the vector of the explanatory variables and $\beta(\tau)$ is the vector of the coefficients associated with the $t$ th quantile. Under these conditions, the previous optimization problem is as follows: 


$$
\hat{\beta}_{n}(\tau)=\arg \min _{\beta(\tau)}\left\{\sum_{i} \rho_{\tau}\left(Y_{i}-X_{i}^{\prime} \beta(\tau)\right)\right\} .
$$

Intuitively, the parameters of $\mathrm{QR}$ are estimated by considering different weights of the absolute residuals. To analyze listing prices, the variable of price per person per night (in logarithmic form) is selected as the dependent variable. As the resulting expression is a semi-logarithmic specification, the coefficient values represent semi-elasticities, namely the percentage change in price when an explanatory variable varies by 1 , having in mind that the effect of a dummy independent variable on a log dependent variable is measured by $\mathrm{e}^{\beta}-1$.

\section{Results}

The data obtained for the explanatory variable of price per person per night are shown in Table 4. Along with the OLS results ${ }^{1}$, estimates of the 10th, 25th, 50th, 75th, and 90th quantiles are provided to demonstrate the effects of the explanatory variables for each quantile. This allows the effects of a specific variable to be distinguished according to the threshold of the dependent variable.

As expected, superhost status leads to higher prices (in particular, according to the semielasticity estimated, the price increases $8.73 \%$ derived from this status $\left.\left(\mathrm{e}^{0.0837}-1=0.0873\right)\right)$. Although the same result is obtained through OLS regression, the quantile coefficients provide richer information, as a decreasing pattern is seen in the coefficients estimated for the quantiles

\footnotetext{
${ }^{1}$ Absence of collinearity has been confirmed for the variables included (with all Variance Inflation Factors standing below 10). In fact, only one of the available review-related items is used (review score for overall rating) as previous collinearity analyses detected some potential issues if all the review-related variables were included. Breusch-Pagan test detected heteroscedasticity, so White heteroskedasticy-consistent standard errors were computed to confirm the significance of all the explanatory variables.
} 
(see Figure 1). These results indicate that even if parameters obtained by OLS regression and by QR have the same sign, the effect estimated using OLS regression may not be constant across quantiles (indeed, the majority of the QR confidence interval falls outside the OLS constant confidence interval). Although superhost status consistently leads to higher prices, this increment is more noticeable among lower-priced listings than among higher-priced listings.

Both OLS regression and QR give positive and significant coefficients for the number of host listings (e.g. the price raises $0.06 \%$ by each listing counted, according to the OLS semielasticity), but the value of the $50^{\text {th }}$ and $75^{\text {th }}$ quantile coefficients are significantly higher and the $90^{\text {th }}$ significantly lower than that of the rest; therefore, this variable has a smaller positive effect on higher-priced listings. Host profile picture has a significant negative parameter, associated with lower prices (the semi-elasticity shows a reduction of $10.89 \%\left(\left(\mathrm{e}^{-0.1154}-1=-0.1089\right)\right)$. Note that this is one of the few variables analyzed whose influence is constant over the conditional distribution of the dependent variable; in other words, the quantile estimates are the same as the OLS results.

Verified host identity yields positive and significant parameters (with an increase in prices of $\left.8.94 \%\left(\mathrm{e}^{0.0856}-1=0.0894\right)\right)$; however, the effects of its quantile parameters take the shape of an inverted U (see Figure 2). The positive effect of verified host identity on price is lowest at the tails of the distribution (the 10th and 90th quantile parameters, or the lowest and highest prices), and reaches its maximum point at the center of the distribution (the 50th quantile parameter). All of these findings support the conclusion reached in previous studies that hosts usually capitalize on a good reputation and professional status (Gutt \& Hermann, 2015; Ikkala \& Lampinen, 2014; Li et al., 2015). 
The variable "distance," representing accommodation location, has a significant negative effect, consistent with the findings of previous studies of hotel price determinants (Bull, 1994; Chen \& Rothschild, 2010; Hung et al., 2010; Lee \& Jang, 2012; Schamel, 2012; White \& Mulligan, 2002; Zhang et al., 2011). The farther the accommodation from the city center, the lower its price; in particular, the estimated semi-elasticity presents a reduction of $0.59 \%$ per kilometer). The pattern of the quantile parameters shows that for high-priced listing (50th, 75th and 90th) this negative effect of distance is greater.

Accommodation types 1 and 2 show a general significant negative effect when compared with reference base of accommodation type 3 (being accommodation type 1 and 2 imply a reduction in prices of $7.94 \%$ and $8.51 \%$ approximately in line with the semi-elasticities obtained $\left(\mathrm{e}^{-0.0851}-1=-0.0794\right.$ and $\left.\left.\mathrm{e}^{-0.0890}-1=-0.0851\right)\right)$; these negative effects of types 1 and 2 are found by both OLS regression and QR. Nevertheless, while the effects detected through OLS are not significantly different between both types (Wald test $=0.53$; $\mathrm{p}$-value $=0.465$ ) -that is, the effects of types 1 and 2 are not different but they are significantly lower than type 3-, the patterns identified through $\mathrm{QR}$ are significantly different (Wald test $=7.35$; $\mathrm{p}$-value $=0.006$ ). Figure 3 not only shows that the conditional quantiles are not identical (with an increasing pattern within each variable) but also that the coefficients differ globally across quantile values between both variables (with one only common value in the 25 th quantile value). The results of this accommodation variable expressed in categories (types)- are especially insightful when it comes to the use of QR together with OLS: not only can one estimate the different impacts of each quantile within each variable but also trace and compare distinct patterns between different variables. To sum up, accommodation types 1 and 2 exert a negative effect on prices compared to type 3 ; however, while 
this negative effect is significant at all times, its negativity reduces as listings raise their prices. In fact, type 2 presents even a positive impact in the high-priced properties (90th quantile).

The reference base for the room types "entire home/apartment" and "private room" is "shared room." Significant and positive parameters (semi-elasticity equal to $144.68 \%\left(\mathrm{e}^{0.8948}\right.$ $1=1.4468)$ ) are obtained for the "entire home/apartment" variable in all cases, with a significant decreasing pattern in the quantile estimates. In other words, the provision of an entire home/apartment leads to higher prices, as expected, but this increment is larger for low-priced listings and smaller for high-priced listings. The "private room" variable shows exactly the same pattern -in both OLS and QR estimates- as the "entire home/apartment" variable (with an OLS semi-elasticity equal to $\left.40.76 \%\left(\mathrm{e}^{0.3419}-1=0.4076\right)\right)$; however, also as expected, the "private room" variable has smaller parameters than the "entire home/apartment," and thus a less positive effect on prices.

The number of people accommodated $(6.1 \%)$ and the provision of bathrooms $(10.8 \%)$, bedrooms (12.4\%), and real beds $(15.5 \%)$ all have positive and significant parameters as obtained by OLS and QR; accommodation is more expensive if it houses more people, provides more bathrooms and bedrooms, and offers real beds. However, an overall increase in quantile estimates is observed for each of the four variables; i.e., their positive effect is stronger for higher-priced properties.

The provision of wireless Internet has a significant and positive parameter (OLS semielasticity equal to $\left.9.98 \%\left(\mathrm{e}^{0.0951}-1=0.0998\right)\right)$, but its quantile estimates show a decreasing pattern; therefore, the increment in price caused by the provision of wireless Internet is more substantial for low-priced listings. This finding is inconsistent with the observation made by hotel industry 
practitioners that low-tariff hotels and hostels are more likely than their high-tariff counterparts to provide Internet access for free (Ren et al., 2016).

The results of OLS regression suggest that the effect on prices of the provision of breakfast is negative and significant (semi-elasticity equal to $\left.1.05 \%\left(\mathrm{e}^{-0.0106}-1=-0.0105\right)\right)$. However, the effect of this variable is null for the $10^{\text {th }}$ and $25^{\text {th }}$ and significant and negative for the 50th, 75th and 90th quantiles. Again, OLS regression indicates a significant negative effect across the price distribution, whereas QR reveals that only those listings priced above average have a significantly negative parameter. This finding is inconsistent with those obtained by hotel industry practitioners (Masiero et al., 2015; Schamel, 2012; Yang et al., 2016). Note that there are only 9\% of all the listings in the sample which offer breakfast. This minority either seems to be a group of hosts that want to especially please their guests or maybe they see breakfast as a relevant item to make their listings more appealing and add it as an extra product which would be in line with the free breakfast effect taking place in hotels (Nicolau and Sellers, 2012).

The provision of free parking on the premises has a significant positive effect (semielasticity equal to $\left.8.44 \%\left(\mathrm{e}^{0.0811}-1=0.0844\right)\right)$ on prices according to both OLS and QR, with a decreasing pattern in the quantile coefficients. The 10th and 25th quantile parameters take higher values than the 50th quantile parameter (which is similar to the OLS estimate), and the 75th and 90th quantile parameters take significantly lower values than the 50th. Therefore, the positive effect of free parking is more acute for low-priced than high-priced listings. This finding is consistent with the results reported by hotel industry practitioners (Espinet et al., 2003; Lee \& Jang, 2012; Saló et al., 2014; Thrane, 2007). However, the QR analysis provides more insightful details on the differences between price groups. 
Instant booking has a negative effect on price (semi-elasticity equal to $6.44 \%\left(\mathrm{e}^{-0.0665}-1=-\right.$ 0.0644)). While this is a positive amenity that helps the guests plan their trip in an easier way, it is linked to lower prices because hosts that seem to look for high occupancy tend to combine both strategies: lower prices to be more attractive and instant booking to be easier to be reserved. This is especially noticeable in listings priced above average, as the 50th, 75th and 90th quantiles are significantly lower (more negative) than the 10th and 25 th quantiles.

Regarding the variable "cancellation policy", first, note that its influence is constant (semielasticity of $\left.4.58 \%\left(\mathrm{e}^{0.0448}-1=0.0458\right)\right)$ over the conditional distribution of the dependent variable (the quantile estimates are not different from the OLS results), and second, non-flexible cancellation ("moderate" to "strict") has a significant positive effect on price. As flexible cancellation policies and low prices are related, it seems that for those hosts (27\% of the sample) who set flexibility in cancellation are driven by emotional factors rather that rational element: they do not care much about securing income, they just want to obtain a fair price and from those guests who really want to come (and if they decide not to come at the last minute this is not an issue). Permission to smoke has a significant negative effect, leading to lower prices (in particular, it leads to a reduction of $\left.23.31 \%\left(\mathrm{e}^{-0.2654}-1=-0.2331\right)\right)$. However, the $10^{\text {th }}, 25$ th and 90 th quantile parameters seem to have smaller negative effects on prices than the 50th and 75 th quantile parameters and the OLS estimates. The hosts allowing their guests to smoke, with their empathy towards smokers, know that this permission could reduce the value of their property, so in an attempt to be more appealing, they tend to charge lower prices. The requirement that a guest profile picture be supplied is not significant according to the results of OLS regression and QR, so this variable does not have any impact on prices. As for the phone verification requirement, the OLS presents a significant and positive effect $\left(2.22 \%\left(\mathrm{e}^{0.0220}-1=0.0222\right)\right)$; this significantly positive 
impact is only found for the 25th and 90th quantiles parameters. It seems that for the $6 \%$ of the sampled hosts that require phone verification, they have a need to feel protected and make sure who the guest coming is in two ways: by verifying the guest via phone and by setting higher prices.

The variable "reviews per year" has a negative effect on price, as indicated by both OLS and QR (as an example, each additional review leads to a price decrease of $0.01 \%\left(\mathrm{e}^{-0.0010}-1=-\right.$ 0.0010)). Previous researchers have reported that most tourists choose to rent sharing economy based accommodation to reduce costs (Balck \& Cracau, 2015; Guttentag, 2015; Quinby \& Gasdia, 2014). Therefore, cheaper listings tend to receive more bookings and consequently more reviews. This happens even in the high-priced listings; the largest parameter of the 90th quantile shows that the most affordable listings among these high-priced properties are the ones that get more reviews. The review scores for rating show a positive parameter, implying an expected positive impact (in particular, this impact is $\left.0.87 \%\left(\mathrm{e}^{0.0087}-1=0.0087\right)\right)$; according to the quantile pattern, the greatest positive effect appears in the low-priced listings.

In an attempt to examine potential heterogeneity in the regions analyzed, Table 6 shows the effect of countries and its interaction with some relevant variables. Taking Greece as the reference base, all other countries have a significant and positive effect on prices. In order to compare each country, Table 7 presents the p-value of the Wald statistical test for each pair of countries. Note that all paired comparisons are significantly different with the exception of USAAustralia, Germany-Austria and Germany-Spain. Therefore, the order from most to less impacting countries on prices is as follows: USA-Australia, Netherlands, Italy, Canada, France, Ireland, UK, Belgium and Spain-Austria-Germany. 
Regarding the interactions, four variables are employed to deal with some basic heterogeneity, focusing on either relevant variables (superhost and accommodation types) or unexpected results in the previous analysis (breakfast and instant booking). While the variable superhost presents a positive effect globally, note that its effect is higher in France than in any other countries. The significant parameter of "superhost" means that this variable is important (positive) in all markets, but France has a positive parameter to be added above the average value

of all countries. As for the accommodation types, the global negative effect of types 1 and 2 (compare to type 3 ) is clearly qualified by the interactions with each country: as Belgium, Italy, Austria, Australia, USA, UK, Ireland, Canada and Germany have positive interactions in both types (1 and 2), the negative effects of these accommodation types is less negative than in any other countries. For example, Spain shows a negative interaction parameter in Type 1 and no significant interaction in Type 2 , so the global negative effect of type 1 is even more acute in this country. In other words, prices in Spain are below average in accommodation Type 1 and aligned with the average in Type 2.

As for "breakfast", the negative effect is prevalent in all countries except Austria and France; so, this apparent anomaly is prevalent in most of the countries analyzed. Finally, concerning "instant booking", the reduction in prices is not really general in all countries; in fact, it only appears in the USA and Canada. The other countries do not have any significant parameter associated with this variable.

\section{Conclusion}

This study investigates the price determinants of sharing economy based accommodation rentals through analysis of 25 variables in 5 categories: host attributes (4 variables), site and 
property attributes (10 variables), amenities and services (5 variables), rental rules (4 variables), and number of online reviews and ratings ( 2 variables). OLS analysis reveals that 24 of the 25 variables under study are good predictors of price, while QR analysis indicates that all of the variables have significant effects on price, but these effects are often dependent on price range. The findings thus offer insights into the complexities of the price-determinant relationship in sharing economy based accommodation rentals.

Specifically, this study identifies the factors determining the price of sharing economy based accommodation, which differ from those determining hotel price. In the hotel industry, stars and chain affiliation have been identified as quality signaling factors (Becerra et al., 2013; Bull, 1994; Chen \& Rothschild, 2010; Israeli, 2002; Masiero et al., 2015; Saló et al., 2014; Schamel, 2012; Yang et al., 2016; Zhang et al., 2011). However, for the rentals available through Airbnb, stars and chain affiliation are irrelevant. Instead, host attributes are identified as important price determinants. Hosts with superhost status, more listings, and verified identities usually charge higher prices. It indicates that Airbnb consumers perceive the aforementioned three variables as one kind of quality signals, and thus would be willing to pay premium prices. However, host profile picture is associated with relatively low rental prices. Although some evidence regarding the impact of racial on rental pricing (Edelman, Luca, \& Svirsky, 2015), there is a lack of empirical evidence from previous studies regarding the impact of the availability of profile pictures.

This study confirms that the factors related with site, property attributes, amenities, services, rental rules, and customer reviews also significantly influence the prices of sharing economy based accommodation rentals, as they do in the hotel industry. In terms of the positive or negative impacts on prices, most of variables show consistent influence as they do in the hotel 
industry. For instance, among site and property attributes, location is a very important price determinant. Using a less typical accommodation type (type 3, e.g., townhouse) as the baseline, the price is found to be lower if the property rented is categorized as an apartment, a condominium, a loft, a property providing bed and breakfast, or a dormitory. However, entire homes/apartments and private rooms are likely to be more expensive than shared rooms. Greater accommodation capacity, indicated by the number of people that can be accommodated, is associated with higher prices, as is the provision of more bathrooms and bedrooms. In terms of amenities and services, prices are higher if real beds, wireless Internet, or free parking are provided. If hosts allow smoking, they usually charge more. Finally, this study reveals the universal power of customer ratings. The higher the average customer rating, the higher the price. However, the number of reviews per year is negatively influencing the rental price.

A few variables were identified as unique in the context of sharing economy based accommodation rentals, including offering breakfast, providing an instant booking service, applying moderate and strict cancellation rules, and requirement of guest verification through profile picture or phone number. This study identifies that prices are lower if the property offers breakfast, which is inconsistent with the findings in hotel industry. This study provides evidence for the impacts of other unique variables. A lower price is more likely to associate with the provision of an instant-booking service. Higher prices are associated with moderate and strict cancellation rules. However, rental price is unaffected by the requirement that guests provide a profile photo or verify their telephone number.

This study takes the initiative to explore the price determinants of sharing economy based accommodation rentals by employing a dataset with the listings in thirty-three cities in thirteen 
countries of three continents. The findings provide a comprehensive understanding of the price determinants of the products in this new business model. With the linear OLS and linear QR analyses, this study not only identifies the price determinants, but also provides hidden priceresponse patterns in different price ranges of the property rentals. This study contributes to the literature regarding the sharing economy by providing a global model summarizing the price determinants of this unconventional accommodation offers. Acknowledging the impact of geographic locations of the rentals (i.e., countries), this study emphasizes the explanatory power of the global model from tourists' perspective, since the demand is determined by tourists from all over the world. Practically, this study provides insights for stakeholders such as accommodation rental suppliers to analyze their market situation and improve profits. Moreover, this study informs the sharing economy based accommodation rental platforms such as Airbnb to design tools to guide suppliers for pricing based on the current price determinants.

Nevertheless, we acknowledge an important limitation of this study. First, economic modeling is used to explore the dataset and identify the associations between various factors and pricing. However, no social or psychological factors governing hosts' price-setting are considered. Therefore, it will be important to conduct qualitative research to explore the rationale for hosts' price decisions. Second, due to space limitation, the scope of this study is set to develop a global model for the price determinants of sharing economy based accommodation rentals. Although the impact of city was considered in this study, the interactions between the city variable and other variables have not been fully explored (only four selected variables are used as an illustrative starting point). Thus, this study does not provide insights on the differences of each price determinant's impact on price in different cities; therefore, future researchers should explore the variation in price-determinant relationships between region and city types. 


\section{References}

About us-Airbnb. (n.d.). Retrived from https://www.airbnb.com/about/about-us.

Airbnb. (n.d.). $\quad$ Retrieved May 2016 11, from https://www.crunchbase.com/organization/airbnb\#/entity.

Balaguer, J., \& Pernías, J. C. (2013). Relationship between spatial agglomeration and hotel prices. Evidence from business and tourism consumers. Tourism Management, 36, 391-400.

Balck, B., \& Cracau, D. (2015). Empirical analysis of customer motives in the shareconomy: a cross-sectoral comparison (Working Paper No. 2/2015). Retrieved from Otto-vonGuericke University Magdeburg, Faculty of Economics and Management website: http://www.fww.ovgu.de/fww_media/femm/femm_2015/2015_02-EGOTECfffac3ecc88b12e16a19a7b0b7850c86.pdf.

Becerra, M., Santaló, J., \& Silva, R. (2013). Being better vs. being different: Differentiation, competition, and pricing strategies in the Spanish hotel industry. Tourism Management, 34, 71-79.

Belk, R. (2014). You are what you can access: Sharing and collaborative consumption online. Journal of Business Research, 67(8), 1595-1600.

Botsman, R. \& Rogers, R. (2010). What's mine is yours: The rise of collaborative consumption. New York, NY: HarperCollins.

Botsman, R., \& Rogers, R. (2011). What's mine is yours: How collaborative consumption is changing the way we live. London: Collins.

Bull, A. O. (1994). Pricing a motel's location. International Journal of Contemporary Hospitality Management, 6(6), 10-15.

Chen, C. F., \& Rothschild, R. (2010). An application of hedonic pricing analysis to the case of hotel rooms in Taipei. Tourism Economics, 16(3), 685-694.

Chen, D. J. (2012). Global concept, local practice: Taiwanese experience of CouchSurfing. Hospitality \& Society, 1(3), 279-297.

Edelman, B. G., Luca, M., \& Svirsky, D. (2015). Racial Discrimination in the Sharing Economy: Evidence from a Field Experiment. Harvard Business School NOM Unit Working Paper, 16-069.

Ert, E., Fleischer, A., \& Magen, N. (2016). Trust and reputation in the sharing economy: The role of personal photos in Airbnb. Tourism Management, 55, 62-73.

Espinet, J. M., Saez, M., Coenders, G., \& Fluvià, M. (2003). Effect on prices of the attributes of holiday hotels: A hedonic prices approach. Tourism Economics, 9(2), 165-177.

Fang, B., Ye, Q., \& Law, R. (2016). Effect of sharing economy on tourism industry employment. Annals of Tourism Research, 57, 264-267.

Gansky, L. (2010). The mesh: Why the future of business is sharing. New York, NY: Portfolio Penguin.

Gansky, L. (2011, August 25). Do more, own less: A grand theory of the sharing economy. The Atlantic. Retrieved from http://www.theatlantic.com/business/archive/2011/08/do-moreown-less-a-grand-theory-of-the-sharing-economy/244141/.

Gkiotsalitis, K. and Stathopoulos, A. (2015), A utility-maximization model for retrieving users' willingness to travel for participating in activities from big-data, Transportation Research Part C: Emerging Technologies, Part B, 58, 265-277.

Guillet, B. D., \& Law, R. (2010). Analyzing hotel star ratings on third-party distribution websites. International Journal of Contemporary Hospitality Management, 22(6), 797-813. 
Gutt, D., \& Herrmann, P. (2015). Sharing means caring? Hosts' price reaction to rating visibility. In ECIS 2015 Research-in-Progress Papers (Paper 54). Retrieved from http://aisel.aisnet.org/ecis2015_rip/54/.

Guttentag, D. (2015). Airbnb: Sisruptive innovation and the rise of an informal tourism accommodation sector. Current Issues in Tourism, 18(12), 1192-1217.

Hamari, J., Sjöklint, M., \& Ukkonen, A. (2015). The sharing economy: Why people participate in collaborative consumption. Journal of the Association for Information Science and Technology. Advance online publication. doi: 10.1002/asi.23552.

Heo, C. Y. (2016). Sharing economy and prospects in tourism research. Annals of Tourism Research, 58, 166-170.

Heo, C. Y., \& Hyun, S. S. (2015). Do luxury room amenities affect guests' willingness to pay? International Journal of Hospitality Management, 46, 161-168.

Hung, W. T., Shang, J. K., \& Wang, F. C. (2010). Pricing determinants in the hotel industry: Quantile regression analysis. International Journal of Hospitality Management, 29(3), 378-384.

Ikkala, T., \& Lampinen, A. (2014, February). Defining the price of hospitality: Networked hospitality exchange via Airbnb. In Proceedings of the Companion Publication of the 17th ACM Conference on Computer Supported Cooperative Work and Social Computing (pp. 173-176). New York, NY: ACM.

Inside Airbnb. (n.d.). Get the data. Retrieved from http://insideairbnb.com/get-the-data.html

Israeli, A. A. (2002). Star rating and corporate affiliation: their influence on room price and performance of hotels in Israel. International Journal of Hospitality Management, 21(4), 405-424.

Kakar, V., Franco, J., Voelz, J., \& Wu, J. (2016). Effects of host race information on Airbnb listing prices in San Francisco. Munich Personal RePEc Archive. Retrieved from https://mpra.ub.uni-muenchen.de/69974/1/MPRA_paper_69974.pdf.

Kaplan, A. M., \& Haenlein, M. (2010). Users of the world, unite! The challenges and opportunities of Social Media. Business horizons, 53(1), 59-68.

Karlsson, L., \& Dolnicar, S. (2016). Someone's been sleeping in my bed. Annals of Tourism Research, 58, 159-162.

Kokalitcheva, K. (2015, June 17). Here's how Airbnb justifies its eye-popping \$24 billion valuation. Fortune. Retrieved from http://fortune.com/2015/06/17/airbnb-valuationrevenue/?iid=sr-link1.

Koenker, R., \& Bassett, G., Jr. (1978). Regression quantiles. Econometrica: Journal of the Econometric Society, 33-50.

Lamberton, C. P., \& Rose, R. L. (2012). When is ours better than mine? A framework for understanding and altering participation in commercial sharing systems. Journal of Marketing, 76(4), 109-125.

Lee, C. G. (2011). The determinants of hotel room rates: Another visit with Singapore's data. International Journal of Hospitality Management, 30(3), 756-758.

Lee, S. K., \& Jang, S. S. (2012). Premium or discount in hotel room rates? The dual effects of a central downtown location. Cornell Hospitality Quarterly, 53(2), 165-173.

Li, J., Moreno, A., \& Zhang, D. J. (2015). Agent behavior in the sharing economy: Evidence from Airbnb. Available at SSRN 2708279.. 
Masiero, L., Nicolau, J. L., \& Law, R. (2015). A demand-driven analysis of tourist accommodation price: A quantile regression of room bookings. International Journal of Hospitality Management, 50, 1-8.

Möhlmann, M. (2015). Collaborative consumption: Determinants of satisfaction and the likelihood of using a sharing economy option again. Journal of Consumer Behaviour, 14(3), 193-207.

Molz, J. G. (2012). CouchSurfing and network hospitality: "It's not just about the furniture." Hospitality \& Society, 1(3), 215-225.

Molz, J. G. (2013). Social networking technologies and the moral economy of alternative tourism: The case of couchsurfing.org. Annals of Tourism Research, 43, 210-230.

Monty, B., \& Skidmore, M. (2003). Hedonic pricing and willingness to pay for bed and breakfast amenities in Southeast Wisconsin. Journal of Travel Research, 42(2), 195-199.

Nicolau, J.L. and Sellers, R. (2012) "The free breakfast effect: an experimental approach to the zero price model in tourism", Journal of Travel Research, 51(3), 243-249.

Pairolero, N. (2016). Assessing the effect of Airbnb on the Washington DC housing market. Available at http://dx.doi.org/10.2139/ssrn.2734109.

Portolan, A. (2013). Impact of the attributes of private tourist accommodation facilities onto prices: A hedonic price approach. European Journal of Tourism Research, 6(1), 74.

Quinby, D., \& Gasdia, M. (2014). Share this! Private accommodation and the rise of the new gen renters. Retrieved from http://www.phocuswright.com/Travel-Research/ConsumerTrends/Share-This-Private-Accommodation-amp-the-Rise-of-the-New-Gen-Renter.

Ren, L., Qiu, H., Wang, P., \& Lin, P. M. (2016). Exploring customer experience with budget hotels: Dimensionality and satisfaction. International Journal of Hospitality Management, 52, 1323.

Saló, A., Garriga, A., Rigall-I-Torrent, R., Vila, M., \& Fluvià, M. (2014). Do implicit prices for hotels and second homes show differences in tourists' valuation for public attributes for each type of accommodation facility? International Journal of Hospitality Management, 36, 120-129.

Schamel, G. (2012). Weekend vs. midweek stays: Modelling hotel room rates in a small market. International Journal of Hospitality Management, 31(4), 1113-1118.

Shengkui, D., Shulin, Z., \& Liao, J. (2013). The new and fashionable tourist group who obtain the confidence and warmth: An elementary research on couchsurfer. Tourism Tribune, 28(7), 101-108.

Steylaerts, V., \& Dubhghaill, S. O. (2012). CouchSurfing and authenticity: Notes towards an understanding of an emerging phenomenon. Hospitality \& Society, 1(3), 261-278.

Sundararajan, A. (2013). From Zipcar to the sharing economy. Harvard Business Review. Retrieved from https://hbr.org/2013/01/from-zipcar-to-the-sharing-eco/.

Sundararajan, A. (2014). Peer-to-peer businesses and the sharing (collaborative) economy: Overview, economic effects and regulatory issues. Written testimony for the hearing titled The Power of Connection: Peer to Peer Businesses, January.

Tang, E., \& Sangani, K. (n.d.). Neighborhood and price prediction for San Francisco Airbnb listings. Retrieved from http://cs229.stanford.edu/proj2015/236_report.pdf.

Thrane, C. (2007). Examining the determinants of room rates for hotels in capital cities: The Oslo experience. Journal of Revenue and Pricing Management, 5(4), 315-323.

Tussyadiah, I. P. (2016). Strategic self-presentation in the sharing economy: Implications for host branding. In A. Inversini, \& R. Schegg (Eds.), Information and Communication Technologies in Tourism 2016 (pp. 695-708). doi 10.1007/978-3-319-28231-2_50. 
Tussyadiah, I. P., \& Pesonen, J. (2015). Impacts of peer-to-peer accommodation use on travel patterns. Journal of Travel Research, 1-19. Advance online publication. doi: $10.1177 / 0047287515608505$.

Tussyadiah, I. P., \& Zach, F. (2015, May). Hotels vs. peer-to-peer accommodation rentals: Text analytics of consumer reviews in Portland, Oregon. Paper presented at the Travel and Tourism Research Association (TTRA) 46th Annual, Portland, OR.

Wang, D., Li, M., Guo, P., \& Xu, W. (2016). The impact of sharing economy on the diversification of tourism products: Implications for tourist experience. In A. Inversini \& R. Schegg (Eds.), Information and Communication Technologies in Tourism 2016 (pp. 683-694). doi 10.1007/978-3-319-28231-2_49.

White, P. J., \& Mulligan, G. F. (2002). Hedonic estimates of lodging rates in the four corners region. The Professional Geographer, 54(4), 533-543.

World Tourism Organization and International Hotel and Restaurant Association. (2004). Joint WTO and IH\&RA Study on Hotel Classification. Retrieved from http://www.eunwto.org/doi/book/10.18111/9789284407194.

Wortham, J. (2011, July 25). Room to rent, via the web. The New York Times. Retrieved from http://www.nytimes.com/2011/07/25/technology/matching-travelers-with-rooms-via-theweb.html?_r=0.

Yang, Y., Luo, H., \& Law, R. (2014). Theoretical, empirical, and operational models in hotel location research. International Journal of Hospitality Management, 36, 209-220.

Yang, Y., Mueller, N. J., \& Croes, R. R. (2016). Market accessibility and hotel prices in the Caribbean: The moderating effect of quality-signaling factors. Tourism Management, 56, 40-51.

Yang, Y., Tang, J., Luo, H., \& Law, R. (2015). Hotel location evaluation: A combination of machine learning tools and web GIS. International Journal of Hospitality Management, 47, $14-24$.

Ye, Q., Law, R., \& Gu, B. (2009). The impact of online user reviews on hotel room sales. International Journal of Hospitality Management, 28(1), 180-182.

Zervas, G., Proserpio, D., \& Byers, J. (2015). A first look at online reputation on Airbnb, where every stay is above average. Retrieved from http://papers.ssrn.com/sol3/papers.cfm?abstract_id=2554500.

Zervas, G., Proserpio, D., \& Byers, J. (2016). The rise of the sharing economy: Estimating the impact of Airbnb on the hotel industry. Boston U. School of Management Research Paper, (2013-16). Retrieved from http://papers.ssrn.com/sol3/papers.cfm?abstract_id=2366898.

Zhang, H., Zhang, J., Lu, S., Cheng, S., \& Zhang, J. (2011). Modeling hotel room price with geographically weighted regression. International Journal of Hospitality Management, 30(4), 1036-1043. 
Table 1. Studies on hotel price determinants

\begin{tabular}{|c|c|c|c|c|}
\hline Dimension & Determinants & Effects & Literature & \multirow{13}{*}{$\begin{array}{l}\text { Details of previous studies } \\
\text { 1. Bull (1994): } 15 \text { motels in Ballina, NSW, } \\
\text { Australia; Hedonic pricing modeling. } \\
\text { 2. Israeli (2002): } 215 \text { Israeli hotels; linear } \\
\text { regression. } \\
\text { 3. White \& Mulligan (2002): } 600 \text { hotels in } \\
\text { southwestern U.S. states; Hedonic price } \\
\text { modeling. } \\
\text { 4. Espinet, Saez, Coenders, \& Fluvia (2003): } \\
\text { 82000 listed price from } 1991 \text { to 1998, Costa } \\
\text { Brava, Spain; Hedonic price. } \\
\text { 5. Thrane (2007): } 74 \text { hotels in Norway; OLS } \\
\text { 6. Chen \& Rothschild (2010): } 73 \text { hotels in } \\
\text { Taiwan, Hedonic pricing method. } \\
\text { 7. Hung, Shang, \& Wang (2010): 58 Taiwan } \\
\text { hotels; quantile regression. } \\
\text { 8. Zhang et al. (2011): } 228 \text { hotels above three star } \\
\text { in Beijing; hedonic price. } \\
\text { 9. Schamel (2012): Online meta-booking engine } \\
\text { trivago.com for hotels in } 10 \text { km vicinity of } \\
\text { Bolzano; Hedonic model. } \\
\text { 10. Lee \& Jang (2012): hotels in Chicago, Spatial } \\
\text { and Aspatial models. } \\
\text { 11. Becerra, Santalo, \& Silva (2013): 1490 hotels } \\
\text { in Spain; OLS. } \\
\text { 12. Salo et al. (2014): 1092 hotels Costa Brava, } \\
\text { Spain; OLS. } \\
\text { 13. Masiero, Nicolau \& Law (2015): Transaction } \\
\text { data for accommodations in Ascona-Locarno, } \\
\text { Ticino, Switzerland, ; OLS and quantile } \\
\text { regression. } \\
\text { 14. Yang, Mueller, \& Croes (2016): hotels in } \\
\text { caribbean, a three-level mixed effect linear } \\
\text { regression model. }\end{array}$} \\
\hline $\begin{array}{c}\text { Site-specific } \\
\text { Characteristics }\end{array}$ & $\begin{array}{l}\text { Location (Distance to city } \\
\text { center/transportation hub/major } \\
\text { attractions/beach) }\end{array}$ & Significant \& Negative & $\begin{array}{l}\text { Bull (1994), Chen and Rothschild (2010), } \\
\text { Hung et al. (2010), Lee and Jang (2012), } \\
\text { Schamel (2012), White and Mulligan } \\
\text { (2002), Zhang et al. (2011). }\end{array}$ & \\
\hline \multirow{3}{*}{$\begin{array}{l}\text { Quality signaling } \\
\text { factors }\end{array}$} & Stars & Significant \& Positive & $\begin{array}{l}\text { Bull (1994), Becerra et al. (2013), Chen and } \\
\text { Rothschild (2010), Israeli (2002), Masiero } \\
\text { et al. (2015), Salo et al. (2014), Schamel } \\
\text { (2012), Yang et al. (2016), Zhang et al. } \\
\text { (2011). }\end{array}$ & \\
\hline & Customer ratings & Significant \& Positive & Schamel (2012), Yang et al. (2016). & \\
\hline & Chain affiliation or not & Mixed & $\begin{array}{l}\text { Positive: Becerra et al. (2013), Chen and } \\
\text { Rothschild (2010), Lee and Jang 2012), } \\
\text { Thrane (2007), White and Mulligan (2002), } \\
\text { Yang et al. (2016). } \\
\text { Negative: Hung et al. (2010), Israeli } \\
\text { (2002). }\end{array}$ & \\
\hline \multirow{4}{*}{$\begin{array}{l}\text { Hotel amenities and } \\
\text { services }\end{array}$} & $\begin{array}{l}\text { Amenities (mini bar, TV, hotel } \\
\text { safe, hair dryer) }\end{array}$ & Significant \& Positive & $\begin{array}{l}\text { Lee \& Jang (2012), Schamel (2012), } \\
\text { Thrane (2007). }\end{array}$ & \\
\hline & Laundry service & Significant \& Negative & Lee \& Jang (2012). & \\
\hline & $\begin{array}{l}\text { Services (Express checkout, } \\
\text { breakfast service, high ratio of } \\
\text { housekeeper and guests, and } \\
\text { advanced booking) }\end{array}$ & Significant \& Positive & $\begin{array}{l}\text { Masiero et al. (2015), Schamel (2012), } \\
\text { Yang et al. (2016) }\end{array}$ & \\
\hline & Internet access & Mixed & $\begin{array}{l}\text { Positive: Chen and Rothschild (2010), } \\
\text { Negative: Schamel (2012), Yang et al. } \\
\text { (2016). }\end{array}$ & \\
\hline \multirow{2}{*}{$\begin{array}{c}\text { Property } \\
\text { characteristics }\end{array}$} & Car parking & Significant \& Positive & $\begin{array}{l}\text { Espinet et al. (2003), Lee and Jang (2012), } \\
\text { Salo et al. (2014), Thrane (2007). }\end{array}$ & \\
\hline & Fitness center & Significant \& Positive & $\begin{array}{l}\text { Chen and Rothschild (2010), Yang et al. } \\
\text { (2016) }\end{array}$ & \\
\hline \multirow{2}{*}{ External factors } & $\begin{array}{l}\text { The number and proximity of } \\
\text { competitors }\end{array}$ & Mixed & $\begin{array}{l}\text { Balaguer and Pernias (2013), Becerra et al. } \\
\text { (2013) }\end{array}$ & \\
\hline & Low market accessibility & Significant \& Positive & Yang et al. (2016) & \\
\hline
\end{tabular}


Table 2 The variable list

\begin{tabular}{|c|c|c|c|}
\hline Variable Name & Mean/proportion & $\begin{array}{l}\text { Standard } \\
\text { deviation }\end{array}$ & Definition \\
\hline Price & 117.18 & 127.87 & Listed price per night in Airbnb.com. (Measured in USdollars). \\
\hline Superhost & 0.09 & 0.29 & $\begin{array}{l}\text { Being a superhost: they have hosted at least } 10 \text { trips; maintained } 90 \% \text { response rate or higher; received a } 5 \text {-star review at least } 80 \% \text { of the time } \\
\text { they have been reviewed; completed each of their confirmed reservations without canceling. (Dummy variable). }\end{array}$ \\
\hline Host listings count & 5.66 & 27.48 & Host's number of accommodation rentals listed in Airbnb.com \\
\hline Host's profile picture & 0.99 & 0.04 & The host has a profile photo (Dummy variable). \\
\hline Host identity verified & 0.64 & 0.47 & The host has completed the Verified ID procedures in Airbnb.com (Dummy variable). \\
\hline Distance & 6.28 & 18.83 & $\begin{array}{l}\text { The distance }(\mathrm{Km}) \text { between the location of a listed rental and the city center, calculated using "Harversine formula" with latitude and longitude } \\
\text { in line with Gkiotsalitis and Stathopoulos (2015) }\end{array}$ \\
\hline Accommodation type 1 & 0.77 & 0.41 & Combined accommodation types: Apartment, condominium and loft. (Dummy variable). \\
\hline Accommodation type 2 & 0.02 & 0.14 & Combined accommodation types: bed \& breakfast, and dorms. (Dummy variable). \\
\hline Accommodation type 3 & 0.20 & 0.40 & Combined accommodation types (reference group): bungalow, house, townhouse, villa, cabin and chalet. (Dummy variable). \\
\hline Entire home/apartment & 0.65 & 0.47 & Entire home/apartment (Dummy variable). \\
\hline Private room & 0.32 & 0.46 & A private room (Dummy variable). \\
\hline Shared room & 0.01 & 0.13 & Shared room with hosts (reference group) \\
\hline Accommodates & 3.25 & 1.97 & The number of people that can be accommodated \\
\hline Bathrooms & 1.20 & 0.54 & The number of bathrooms \\
\hline Bedrooms & 1.30 & 0.85 & The number of bedrooms \\
\hline Real bed & 0.95 & 0.21 & Offer a real bed (versus other types of beds such as airbed). (Dummy variable). \\
\hline Wireless Internet & 0.94 & 0.23 & Offer wireless Internet access. (Dummy variable). \\
\hline Breakfast & 0.09 & 0.287 & Offer breakfast. (Dummy variable). \\
\hline Free parking & 0.26 & 0.44 & Offer free parking. (Dummy variable). \\
\hline Instant bookable & 0.16 & 0.37 & Offer instant booking. (Dummy variable). \\
\hline Cancellation policy (Moderate plus strict) & 0.73 & 0.43 & No cancellation or penalty applies. (Dummy variable). \\
\hline Smoking allowed & 0.12 & 0.33 & Smoking is allowed. (Dummy variable). \\
\hline Required guest's profile picture & 0.04 & 0.20 & Require guest's profile picture for booking approval. (Dummy variable). \\
\hline Required guest's phone verification & 0.06 & 0.24 & Require guest phone number for booking approval. (Dummy variable). \\
\hline Reviews per year & 9.65 & 14.41 & The ratio of total number of reviews over the years that the rental was first listed \\
\hline Review scores for overall rating & 92.08 & 9.09 & Overall review scores. (Interval scales between 20 and 100). \\
\hline
\end{tabular}


Table 3 Details of the dataset

\begin{tabular}{|c|c|c|c|c|c|c|}
\hline No. & 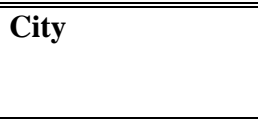 & Region & Country & Date Compiled & $\begin{array}{c}\text { Total } \\
\text { Listings }\end{array}$ & $\begin{array}{l}\text { Selected Listings } \\
\text { (with at least one } \\
\text { review per year) }\end{array}$ \\
\hline 1 & Amsterdam & North Holland & $\begin{array}{l}\text { The } \\
\text { Netherlands }\end{array}$ & 03 January, 2016 & 10863 & 7525 \\
\hline 2 & Antwerp & Flemish Region & Belgium & 03 October, 2015 & 737 & 522 \\
\hline 3 & Athens & Attica & Greece & 17 July, 2015 & 2108 & 1373 \\
\hline 4 & Austin & Texas & United States & 07 November, 2015 & 5731 & 2926 \\
\hline 5 & Barcelona & Catalonia & Spain & 03 January, 2016 & 14742 & 9392 \\
\hline 6 & Berlin & Berlin & Germany & 03 October, 2015 & 15305 & 9910 \\
\hline 7 & Boston & Massachusetts & United States & 03 October, 2015 & 2537 & 1759 \\
\hline 8 & Brussels & Brussels & Belgium & 03 October, 2015 & 4893 & 3085 \\
\hline 9 & Chicago & Illinois & United States & 03 October, 2015 & 5122 & 3632 \\
\hline 10 & Dublin & Leinster & Ireland & 06 January, 2016 & 3739 & 2690 \\
\hline 11 & London & England & $\begin{array}{l}\text { United } \\
\text { Kingdom }\end{array}$ & 02 February, 2016 & 33515 & 19682 \\
\hline 12 & Los Angeles & California & United States & 02 January, 2016 & 20215 & 12404 \\
\hline 13 & Madrid & Region of Madrid & Spain & 02 October, 2015 & 7408 & 4743 \\
\hline 14 & Mallorca & Islas Baleares & Spain & 06 January, 2016 & 11132 & 4524 \\
\hline 15 & Melbourne & Victoria & Australia & 03 January, 2016 & 8581 & 4883 \\
\hline 16 & Montreal & Quebec & Canada & 02 October, 2015 & 8950 & 5074 \\
\hline 17 & Nashville & Tennessee & United States & 03 October, 2015 & 2093 & 1504 \\
\hline 18 & New Orleans & Louisiana & United States & 03 February, 2016 & 3562 & 2387 \\
\hline 19 & New York City & New York & United States & 02 February, 2016 & 35851 & 21733 \\
\hline 20 & Oakland & California & United States & 22 June, 2015 & 1142 & 713 \\
\hline 21 & Paris & Île-de-France & France & 02 February, 2016 & 41383 & 26472 \\
\hline 22 & Portland & Oregon & United States & 01 January, 2016 & 2762 & 2206 \\
\hline 23 & San Diego & California & United States & 22 June, 2015 & 3448 & 1977 \\
\hline 24 & San Francisco & California & United States & 01 November, 2015 & 6949 & 4650 \\
\hline 25 & Santa Cruz County & California & United States & 15 October, 2015 & 777 & 630 \\
\hline 26 & Seattle & Washington & United States & 04 January, 2016 & 3766 & 2778 \\
\hline 27 & Sydney & New South Wales & Australia & 03 January, 2016 & 16045 & 6633 \\
\hline 28 & Toronto & Ontario & Canada & 03 September, 2015 & 6684 & 3705 \\
\hline 29 & Trentino & $\begin{array}{l}\text { Trentino-Alto } \\
\text { Adige/Südtirol }\end{array}$ & Italy & 12 October, 2015 & 1831 & 712 \\
\hline 30 & Vancouver & British Columbia & Canada & 03 December, 2015 & 4701 & 3058 \\
\hline 31 & Venice & Veneto & Italy & 18 July, 2015 & 3105 & 2275 \\
\hline 32 & Vienna & Vienna & Austria & 18 July, 2015 & 4945 & 2601 \\
\hline \multirow[t]{2}{*}{33} & Washington, D.C. & District of Columbia & United States & 03 October, 2015 & 3709 & 2375 \\
\hline & & & & Total & 298331 & 180533 \\
\hline
\end{tabular}


Table 4. Determinants of price per night (OLS and quantile regression)

(Standard errors in parenthesis)

\begin{tabular}{|c|c|c|c|c|c|c|}
\hline \multirow{2}{*}{ Variables } & \multirow{2}{*}{ OLS } & \multicolumn{5}{|c|}{ Quantiles } \\
\hline & & 0.1 & 0.25 & 0.5 & 0.75 & 0.9 \\
\hline Constant & $\begin{array}{c}2.4083^{\mathrm{a}} \\
(0.0296)\end{array}$ & $\begin{array}{c}1.8154^{\mathrm{a}} \\
(0.0443)\end{array}$ & $\begin{array}{c}2.0438^{\mathrm{a}} \\
(0.0426)\end{array}$ & $\begin{array}{c}2.3263^{\mathrm{a}} \\
(0.0451)\end{array}$ & $\begin{array}{c}2.7156^{\mathrm{a}} \\
(0.0484)\end{array}$ & $\begin{array}{c}3.0724^{\mathrm{a}} \\
(0.0447)\end{array}$ \\
\hline \multicolumn{7}{|l|}{ Host Attributes } \\
\hline Superhost & $\begin{array}{c}0.0837^{\mathrm{a}} \\
(0.0039)\end{array}$ & $\begin{array}{c}0.1206^{\mathrm{a}} \\
(0.0061)\end{array}$ & $\begin{array}{c}0.1102^{\mathrm{a}} \\
(0.0048)\end{array}$ & $\begin{array}{c}0.0807^{\mathrm{a}} \\
(0.0041)\end{array}$ & $\begin{array}{c}0.0534^{\mathrm{a}} \\
(0.0046)\end{array}$ & $\begin{array}{r}0.0422^{\mathrm{a}} \\
(0.0064)\end{array}$ \\
\hline Host listings count & $\begin{array}{c}0.0006^{\mathrm{a}} \\
(0.0001)\end{array}$ & $\begin{array}{c}0.0007^{a} \\
(0.0002)\end{array}$ & $\begin{array}{c}0.0006^{\mathrm{a}} \\
(0.0001)\end{array}$ & $\begin{array}{c}0.0008^{a} \\
(0.0001)\end{array}$ & $\begin{array}{c}0.0008^{a} \\
(0.0001)\end{array}$ & $\begin{array}{c}0.0005^{\mathrm{a}} \\
(0.0001)\end{array}$ \\
\hline Host's profile picture & $\begin{array}{l}-0.1154^{\mathrm{a}} \\
(0.0241)\end{array}$ & $\begin{array}{l}-0.0856^{\mathrm{a}} \\
(0.0267)\end{array}$ & $\begin{array}{l}-0.0994^{a} \\
(0.0330)\end{array}$ & $\begin{array}{l}-0.1142^{\mathrm{a}} \\
(0.0392)\end{array}$ & $\begin{array}{l}-0.1313^{\mathrm{a}} \\
(0.0414)\end{array}$ & $\begin{array}{l}-0.1473^{\mathrm{a}} \\
(0.0357)\end{array}$ \\
\hline Host identity verified & $\begin{array}{c}0.0856^{\mathrm{a}} \\
(0.0025)\end{array}$ & $\begin{array}{c}0.0679^{a} \\
(0.0039)\end{array}$ & $\begin{array}{c}0.0843^{a} \\
(0.0031)\end{array}$ & $\begin{array}{c}0.0948^{a} \\
(0.0029)\end{array}$ & $\begin{array}{c}0.0861^{a} \\
(0.0033)\end{array}$ & $\begin{array}{c}0.0767^{a} \\
(0.0042)\end{array}$ \\
\hline \multicolumn{7}{|c|}{ Site \& Property Attributes } \\
\hline Distance $(\mathrm{km})$ & $\begin{array}{l}-0.0059^{\mathrm{a}} \\
(0.0002)\end{array}$ & $\begin{array}{l}-0.0053^{\mathrm{a}} \\
(0.0003)\end{array}$ & $\begin{array}{l}-0.0054^{a} \\
(0.0002)\end{array}$ & $\begin{array}{l}-0.0058^{\mathrm{a}} \\
(0.0002)\end{array}$ & $\begin{array}{l}-0.0062^{\mathrm{a}} \\
(0.0003)\end{array}$ & $\begin{array}{c}-0.0063^{\mathrm{a}} \\
(0.0003)\end{array}$ \\
\hline Accommodation type 1 & $\begin{array}{l}-0.0827^{a} \\
(0.0033)\end{array}$ & $\begin{array}{l}-0.1390^{\mathrm{a}} \\
(0.0056)\end{array}$ & $\begin{array}{l}-0.1073^{\mathrm{a}} \\
(0.0043)\end{array}$ & $\begin{array}{l}-0.0619^{\mathrm{a}} \\
(0.0038)\end{array}$ & $\begin{array}{l}-0.0422^{\mathrm{a}} \\
(0.0042)\end{array}$ & $\begin{array}{c}-0.0329^{\mathrm{a}} \\
(0.0058)\end{array}$ \\
\hline Accommodation type 2 & $\begin{array}{l}-0.0890^{\mathrm{a}} \\
(0.0088)\end{array}$ & $\begin{array}{l}-0.2483^{a} \\
(0.0193)\end{array}$ & $\begin{array}{l}-0.1175^{a} \\
(0.0147)\end{array}$ & $\begin{array}{c}-0.0303^{b} \\
(0.0119)\end{array}$ & $\begin{array}{c}0.0345^{\mathrm{a}} \\
(0.0113)\end{array}$ & $\begin{array}{r}0.0556^{a} \\
(0.0162)\end{array}$ \\
\hline Entire home/apartment & $\begin{array}{c}0.8948^{\mathrm{a}} \\
(0.0090)\end{array}$ & $\begin{array}{c}1.0371^{\mathrm{a}} \\
(0.0151)\end{array}$ & $\begin{array}{c}0.9555^{\mathrm{a}} \\
(0.0127)\end{array}$ & $\begin{array}{c}0.8419^{\mathrm{a}} \\
(0.0128)\end{array}$ & $\begin{array}{c}0.7535^{\mathrm{a}} \\
(0.0171)\end{array}$ & $\begin{array}{c}0.6667^{a} \\
(0.0187)\end{array}$ \\
\hline Private room & $\begin{array}{c}0.3419^{a} \\
(0.0090)\end{array}$ & $\begin{array}{c}0.4097^{a} \\
(0.0148)\end{array}$ & $\begin{array}{c}0.3727^{a} \\
(0.0128)\end{array}$ & $\begin{array}{c}0.3162^{a} \\
(0.0128)\end{array}$ & $\begin{array}{c}0.2582^{a} \\
(0.0169)\end{array}$ & $\begin{array}{r}0.1735^{a} \\
(0.0183)\end{array}$ \\
\hline Accommodates & $\begin{array}{c}0.0616^{\mathrm{a}} \\
(0.0010)\end{array}$ & $\begin{array}{c}0.0554^{\mathrm{a}} \\
(0.0015)\end{array}$ & $\begin{array}{c}0.0589^{a} \\
(0.0012)\end{array}$ & $\begin{array}{c}0.0660^{a} \\
(0.0014)\end{array}$ & $\begin{array}{c}0.0711^{a} \\
(0.0016)\end{array}$ & $\begin{array}{r}0.0780^{\mathrm{a}} \\
(0.0021)\end{array}$ \\
\hline Bathrooms & $\begin{array}{c}0.1085^{a} \\
(0.0027)\end{array}$ & $\begin{array}{c}0.0515^{a} \\
(0.0039)\end{array}$ & $\begin{array}{c}0.0798^{a} \\
(0.0040)\end{array}$ & $\begin{array}{c}0.1237^{a} \\
(0.0042)\end{array}$ & $\begin{array}{c}0.1705^{a} \\
(0.0055)\end{array}$ & $\begin{array}{r}0.2092^{\mathrm{a}} \\
(0.0067)\end{array}$ \\
\hline Bedrooms & $\begin{array}{c}0.1249^{a} \\
(0.0021)\end{array}$ & $\begin{array}{c}0.0976^{\mathrm{a}} \\
(0.0031)\end{array}$ & $\begin{array}{c}0.1111^{\mathrm{a}} \\
(0.0027)\end{array}$ & $\begin{array}{c}0.1216^{\mathrm{a}} \\
(0.0029)\end{array}$ & $\begin{array}{c}0.1318^{a} \\
(0.0034)\end{array}$ & $\begin{array}{c}0.1275^{a} \\
(0.0043)\end{array}$ \\
\hline Amenities \& Services & & & & & & \\
\hline Real bed & $\begin{array}{c}0.1555^{\mathrm{a}} \\
(0.0055)\end{array}$ & $\begin{array}{c}0.0819^{\mathrm{a}} \\
(0.0070)\end{array}$ & $\begin{array}{c}0.1244^{\mathrm{a}} \\
(0.0060)\end{array}$ & $\begin{array}{c}0.1831^{\mathrm{a}} \\
(0.0055)\end{array}$ & $\begin{array}{c}0.2106^{\mathrm{a}} \\
(0.0083)\end{array}$ & $\begin{array}{r}0.2336^{\mathrm{a}} \\
(0.0085)\end{array}$ \\
\hline Wireless Internet & $\begin{array}{c}0.0951^{\mathrm{a}} \\
(0.0052)\end{array}$ & $\begin{array}{c}0.1331^{\mathrm{a}} \\
(0.0089)\end{array}$ & $\begin{array}{c}0.1262^{\mathrm{a}} \\
(0.0073)\end{array}$ & $\begin{array}{c}0.0886^{a} \\
(0.0068)\end{array}$ & $\begin{array}{c}0.0646^{\mathrm{a}} \\
(0.0076)\end{array}$ & $\begin{array}{c}0.0751^{\mathrm{a}} \\
(0.0099)\end{array}$ \\
\hline Breakfast & $\begin{array}{l}-0.0106^{a} \\
(0.0042)\end{array}$ & $\begin{array}{c}0.0108 \\
(0.0068)\end{array}$ & $\begin{array}{l}-0.0031 \\
(0.0054)\end{array}$ & $\begin{array}{c}-0.0103^{b} \\
(0.0048)\end{array}$ & $\begin{array}{l}-0.0253^{a} \\
(0.0055)\end{array}$ & $\begin{array}{l}-0.0210^{\mathrm{a}} \\
(0.0099)\end{array}$ \\
\hline Free parking & $\begin{array}{c}0.0811^{\mathrm{a}} \\
(0.0029)\end{array}$ & $\begin{array}{c}0.1184^{\mathrm{a}} \\
(0.0049)\end{array}$ & $\begin{array}{c}0.1103^{\mathrm{a}} \\
(0.0037)\end{array}$ & $\begin{array}{c}0.0891^{\mathrm{a}} \\
(0.0033)\end{array}$ & $\begin{array}{c}0.0433^{\mathrm{a}} \\
(0.0036)\end{array}$ & $\begin{array}{c}0.0084 \\
(0.0049)\end{array}$ \\
\hline Instant bookable & $\begin{array}{l}-0.0665^{a} \\
(0.0031)\end{array}$ & $\begin{array}{l}-0.0606^{\mathrm{a}} \\
(0.0048)\end{array}$ & $\begin{array}{l}-0.0614^{a} \\
(0.0040)\end{array}$ & $\begin{array}{l}-0.0607^{a} \\
(0.0036)\end{array}$ & $\begin{array}{l}-0.0680^{a} \\
(0.0041)\end{array}$ & $\begin{array}{l}-0.0756^{\mathrm{a}} \\
(0.0051)\end{array}$ \\
\hline Rental Rules & & & & & & \\
\hline Cancellation policy (Moderate plus strict) & $\begin{array}{c}0.0448^{\mathrm{a}} \\
(0.0028)\end{array}$ & $\begin{array}{c}0.0446^{\mathrm{a}} \\
(0.0043)\end{array}$ & $\begin{array}{c}0.0431^{\mathrm{a}} \\
(0.0035)\end{array}$ & $\begin{array}{c}0.0478^{\mathrm{a}} \\
(0.0034)\end{array}$ & $\begin{array}{c}0.0490^{\mathrm{a}} \\
(0.0039)\end{array}$ & $\begin{array}{c}0.0406^{\mathrm{a}} \\
(0.0049)\end{array}$ \\
\hline Smoking allowed & $\begin{array}{l}-0.2654^{a} \\
(0.0035)\end{array}$ & $\begin{array}{l}-0.2253^{a} \\
(0.0053)\end{array}$ & $\begin{array}{l}-0.2536^{a} \\
(0.0042)\end{array}$ & $\begin{array}{l}-0.2804^{\mathrm{a}} \\
(0.0040)\end{array}$ & $\begin{array}{l}-0.2876^{a} \\
(0.0050)\end{array}$ & $\begin{array}{l}-0.2588^{a} \\
(0.0063)\end{array}$ \\
\hline Required guest's profile picture & $\begin{array}{c}0.0102 \\
(0.0082)\end{array}$ & $\begin{array}{c}0.0096 \\
(0.0126)\end{array}$ & $\begin{array}{c}-0.0008 \\
(0.0101)\end{array}$ & $\begin{array}{c}0.0178 \\
(0.0103)\end{array}$ & $\begin{array}{c}0.0096 \\
(0.0095)\end{array}$ & $\begin{array}{c}0.0197 \\
(0.0129)\end{array}$ \\
\hline Required guest's phone verification & $\begin{array}{c}0.0220^{\mathrm{a}} \\
(0.0071)\end{array}$ & $\begin{array}{c}0.0217 \\
(0.0115)\end{array}$ & $\begin{array}{c}0.0303^{a} \\
(0.0085)\end{array}$ & $\begin{array}{c}0.0172 \\
(0.0090)\end{array}$ & $\begin{array}{c}0.0272 \\
(0.0088)\end{array}$ & $\begin{array}{c}0.0141^{a} \\
(0.0105)\end{array}$ \\
\hline Online Reviews: Number \& & & & & & & \\
\hline Reviews per year & $\begin{array}{l}-0.0010^{\mathrm{a}} \\
(0.0001)\end{array}$ & $\begin{array}{l}0.00004 \\
(0.0001)\end{array}$ & $\begin{array}{c}-0.0002^{b} \\
(0.0001)\end{array}$ & $\begin{array}{l}-0.0007^{\mathrm{a}} \\
(0.0001)\end{array}$ & $\begin{array}{l}-0.0015^{\mathrm{a}} \\
(0.0001)\end{array}$ & $\begin{array}{l}-0.0022^{\mathrm{a}} \\
(0.0001)\end{array}$ \\
\hline Review scores for rating & $\begin{array}{c}0.0087^{\mathrm{a}} \\
(0.0001) \\
\end{array}$ & $\begin{array}{c}0.0091^{\mathrm{a}} \\
(0.0003) \\
\end{array}$ & $\begin{array}{c}0.0091^{\mathrm{a}} \\
(0.0002) \\
\end{array}$ & $\begin{array}{c}0.0091^{\mathrm{a}} \\
(0.0002) \\
\end{array}$ & $\begin{array}{c}0.0086^{\mathrm{a}} \\
(0.0002) \\
\end{array}$ & $\begin{array}{r}0.0082^{\mathrm{a}} \\
(0.0002) \\
\end{array}$ \\
\hline
\end{tabular}


Table 5. Significant differences among quantiles (p-values)

\begin{tabular}{lllll}
\hline \hline & $\mathbf{0 . 1 , 0 . 2 5}$ & $\mathbf{0 . 2 5 , \boldsymbol { 0 . 5 }}$ & $\mathbf{0 . 5 , 0 . 7 5}$ & $\mathbf{0 . 7 5 , \boldsymbol { 0 . 9 }}$ \\
\hline Superhost & 0.0453 & 0.0000 & 0.0000 & 0.0375 \\
Host listings count & 0.4141 & 0.0443 & 0.9719 & 0.0007 \\
Host's profile picture & 0.6235 & 0.6601 & 0.6456 & 0.6561 \\
Host identity verified & 0.0000 & 0.0002 & 0.0026 & 0.0088 \\
Distance (km) & 0.7926 & 0.0160 & 0.0866 & 0.6619 \\
Accommodation type 1 & 0.0000 & 0.0000 & 0.0000 & 0.0542 \\
Accommodation type 2 & 0.0000 & 0.0000 & 0.0000 & 0.1158 \\
Entire home/apartment & 0.0000 & 0.0000 & 0.0000 & 0.0000 \\
Private room & 0.0044 & 0.0000 & 0.0000 & 0.0000 \\
Accommodates & 0.0051 & 0.0000 & 0.0002 & 0.0001 \\
Bathrooms & 0.0000 & 0.0000 & 0.0000 & 0.0000 \\
Bedrooms & 0.0000 & 0.0001 & 0.0005 & 0.2335 \\
Real bed & 0.0000 & 0.0000 & 0.0001 & 0.0030 \\
Wireless Internet & 0.3647 & 0.0000 & 0.0003 & 0.2084 \\
Breakfast & 0.0158 & 0.1248 & 0.0019 & 0.4780 \\
Free parking & 0.0502 & 0.0000 & 0.0000 & 0.0000 \\
Instant bookable & 0.8393 & 0.8327 & 0.0417 & 0.0816 \\
Cancellation policy (Moderate plus strict) & 0.6690 & 0.1375 & 0.7102 & 0.0418 \\
Smoking allowed & 0.0000 & 0.0000 & 0.0893 & 0.0000 \\
Required guest's profile picture & 0.3308 & 0.0469 & 0.3669 & 0.3502 \\
Required guest's phone verification & 0.3712 & 0.1066 & 0.2294 & 0.1488 \\
Reviews per year & 0.0676 & 0.0000 & 0.0000 & 0.0000 \\
Review scores for rating & 0.9351 & 0.8585 & 0.0063 & 0.0533
\end{tabular}


Table 6. Basic heterogeneity by countries

(Standard errors in parenthesis)

\begin{tabular}{|c|c|c|c|c|c|c|c|c|}
\hline \multirow{2}{*}{$\frac{\text { Variable }}{\mathrm{C}}$} & \multirow{2}{*}{$\begin{array}{c}\text { Countries } \\
3.8492^{\mathrm{a}} \\
(0.0163)\end{array}$} & \multicolumn{2}{|l|}{$\begin{array}{r}\text { Superhost } \\
(\text { sh) }\end{array}$} & $\begin{array}{r}\begin{array}{r}\text { Accommodation } \\
\text { type }\end{array} \\
\text { res }\end{array}$ & \multicolumn{2}{|l|}{$\begin{array}{r}\text { Breakfast } \\
\text { (bf) }\end{array}$} & \multicolumn{2}{|l|}{$\begin{array}{r}\text { Instant bookable } \\
\text { (ib) }\end{array}$} \\
\hline & & Superhost & $\begin{array}{l}0.0962^{\mathrm{b}} \\
(0.0466)\end{array}$ & Type1 & $\begin{array}{l}-0.1264^{\mathrm{b}} \text { Breakfast } \\
(0.0623)\end{array}$ & $\begin{array}{l}-0.0702 \\
(0.0436)\end{array}$ & Instant bookable & $\begin{array}{c}0.0303 \\
(0.0368)\end{array}$ \\
\hline Belgium & $\begin{array}{l}0.2648^{\mathrm{a}} \\
(0.0192)\end{array}$ & Belgium*sh & $\begin{array}{c}0.0547 \\
(0.0613)\end{array}$ & Type2 & $\begin{array}{l}-0.9796^{a} \text { Belgium*bf } \\
(0.1165)\end{array}$ & $\begin{array}{l}-0.0175 \\
(0.0545)\end{array}$ & Belgium*ib & $\begin{array}{l}-0.0417 \\
(0.0456)\end{array}$ \\
\hline Italy & $\begin{array}{l}0.6985^{\mathrm{a}} \\
(0.0197)\end{array}$ & Italy*sh & $\begin{array}{l}-0.0503 \\
(0.0575)\end{array}$ & Belgium*Type1 & $\begin{array}{l}0.2418^{a} \text { Italy*bf } \\
(0.0689)\end{array}$ & $\begin{array}{l}-0.2281^{\mathrm{a}} \\
(0.0515)\end{array}$ & Italy*ib & $\begin{array}{c}0.0456 \\
(0.0443)\end{array}$ \\
\hline Austria & $\begin{array}{l}0.1990^{\mathrm{a}} \\
(0.0202)\end{array}$ & Austria*sh & $\begin{array}{c}0.1109 \\
(0.0580)\end{array}$ & Italy*Type1 & $\begin{array}{l}0.3508^{a} \text { Austria*bf } \\
(0.0735)\end{array}$ & $\begin{array}{c}0.0369 \\
(0.0713)\end{array}$ & Austria*ib & $\begin{array}{c}0.0060 \\
(0.0474)\end{array}$ \\
\hline Australia & $\begin{array}{l}0.9292^{\mathrm{a}} \\
(0.0172)\end{array}$ & Australia*sh & $\begin{array}{l}-0.0665 \\
(0.0505)\end{array}$ & Austria*Type1 & $\begin{array}{l}0.2647^{a} \text { Australia*bf } \\
(0.0987)\end{array}$ & $\begin{array}{l}-0.1815^{\mathrm{a}} \\
(0.0463)\end{array}$ & Australia*ib & $\begin{array}{l}-0.0459 \\
(0.0399)\end{array}$ \\
\hline USA & $\begin{array}{l}0.9296^{\mathrm{a}} \\
(0.0165)\end{array}$ & USA*sh & $\begin{array}{l}-0.0531 \\
(0.0471)\end{array}$ & Australia*Type 1 & $\begin{array}{l}0.2328^{\mathrm{a}} \mathrm{USA}^{*} \mathrm{bf} \\
(0.0635)\end{array}$ & $\begin{array}{l}-0.1596^{a} \\
(0.0445)\end{array}$ & United_states*ib & $\begin{array}{l}-0.1566^{a} \\
(0.0374)\end{array}$ \\
\hline France & $\begin{array}{l}0.5280^{\mathrm{a}} \\
(0.0167)\end{array}$ & France*sh & $\begin{array}{l}0.1194^{\mathrm{b}} \\
(0.0487)\end{array}$ & USA *Type1 & $\begin{array}{l}0.1420^{\mathrm{b}} \text { France*bf } \\
(0.0625)\end{array}$ & $\begin{array}{l}-0.0505 \\
(0.0456)\end{array}$ & France*ib & $\begin{array}{c}0.0428 \\
(0.0380)\end{array}$ \\
\hline UK & $\begin{array}{l}0.4328^{\mathrm{a}} \\
(0.0169)\end{array}$ & $\mathrm{UK} * \mathrm{sh}$ & $\begin{array}{l}-0.0843 \\
(0.0487)\end{array}$ & France*Type1 & $\begin{array}{l}-0.1117 \mathrm{UK} * \mathrm{bf} \\
(0.0719)\end{array}$ & $\begin{array}{l}-0.2579^{\mathrm{a}} \\
(0.0453)\end{array}$ & United_kingdom*ib & $\begin{array}{r}-0.0627 \\
(0.0383)\end{array}$ \\
\hline Spain & $\begin{array}{l}0.2042^{\mathrm{a}} \\
(0.0169)\end{array}$ & Spain*sh & $\begin{array}{c}0.0219 \\
(0.0512)\end{array}$ & UK *Type 1 & $\begin{array}{l}0.4352^{a} \text { Spain*bf } \\
(0.0632)\end{array}$ & $\begin{array}{l}-0.2997^{a} \\
(0.0461)\end{array}$ & Spain*ib & $\begin{array}{l}-0.0286 \\
(0.0381)\end{array}$ \\
\hline Ireland & $\begin{array}{l}0.4611^{\mathrm{a}} \\
(0.0200)\end{array}$ & Ireland*sh & $\begin{array}{l}-0.0687 \\
(0.0576)\end{array}$ & Spain*Type1 & $\begin{array}{l}-0.2667^{\mathrm{a}} \text { Ireland*bf } \\
(0.0637)\end{array}$ & $\begin{array}{l}-0.2080^{a} \\
(0.0515)\end{array}$ & Ireland*ib & $\begin{array}{c}0.0256 \\
(0.0486)\end{array}$ \\
\hline Netherlands & $\begin{array}{l}0.8762^{\mathrm{a}} \\
(0.0177)\end{array}$ & Netherlands*sh & $\begin{array}{l}-0.0142 \\
(0.0520)\end{array}$ & Ireland*Type1 & $\begin{array}{l}0.3098^{a} \text { Netherlands*bf } \\
(0.0669)\end{array}$ & $\begin{array}{l}-0.1230^{\mathrm{b}} \\
(0.0514)\end{array}$ & Netherlands*ib & $\begin{array}{l}-0.0320 \\
(0.0429)\end{array}$ \\
\hline Canada & $\begin{array}{l}0.6454^{\mathrm{a}} \\
(0.0172)\end{array}$ & Canada*sh & $\begin{array}{c}0.0617 \\
(0.0499)\end{array}$ & Netherlands*Type 1 & $\begin{array}{l}0.0054 \text { Canada*bf } \\
(0.0662)\end{array}$ & $\begin{array}{l}-0.1298^{\mathrm{a}} \\
(0.0486)\end{array}$ & Canada*ib & $\begin{array}{l}-0.1877^{a} \\
(0.0402)\end{array}$ \\
\hline Germany & $\begin{array}{l}0.1127^{\mathrm{a}} \\
(0.0174)\end{array}$ & Germany* sh & $\begin{array}{c}0.0482 \\
(0.0536)\end{array}$ & Canada*Type1 & $\begin{array}{l}0.1540^{\mathrm{b}} \text { Germany*bf } \\
(0.0638)\end{array}$ & $\begin{array}{l}-0.1537^{\mathrm{a}} \\
(0.0561)\end{array}$ & Germany*ib & $\begin{array}{c}0.0770 \\
(0.0408)\end{array}$ \\
\hline & & & & Germany*Type1 & $\begin{array}{l}0.2506^{\mathrm{a}} \\
(0.0740)\end{array}$ & & Belgium*ib & $\begin{array}{l}-0.0417 \\
(0.0456)\end{array}$ \\
\hline & & & & Belgium*Type2 & $\begin{array}{l}1.0682^{\mathrm{a}} \\
(0.1305)\end{array}$ & & & \\
\hline & & & & Italy*Type2 & $\begin{array}{l}0.8640^{\mathrm{a}} \\
(0.1255)\end{array}$ & & & \\
\hline & & & & Austria*Type2 & $\begin{array}{l}0.7085^{\mathrm{a}} \\
(0.1805)\end{array}$ & & & \\
\hline & & & & Australia*Type2 & $\begin{array}{l}0.7061^{a} \\
(0.1227)\end{array}$ & & & \\
\hline & & & & USA *Type2 & $\begin{array}{l}0.5984^{a} \\
(0.1187)\end{array}$ & & & \\
\hline & & & & France*Type 2 & $\begin{array}{l}0.5206^{\mathrm{a}} \\
(0.1290)\end{array}$ & & & \\
\hline & & & & UK *Type2 & $\begin{array}{l}0.7608^{a} \\
(0.1197)\end{array}$ & & & \\
\hline & & & & Spain*Type2 & $\begin{array}{c}0.1052 \\
(0.1192)\end{array}$ & & & \\
\hline & & & & Ireland*Type2 & $\begin{array}{l}0.7207^{\mathrm{a}} \\
(0.1297)\end{array}$ & & & \\
\hline & & & & Netherlands*Type2 & $\begin{array}{l}0.6000^{\mathrm{a}} \\
(0.1233)\end{array}$ & & & \\
\hline & & & & Canada*Type2 & $\begin{array}{l}0.5726^{a} \\
(0.1292)\end{array}$ & & & \\
\hline & & & & Germany*Type2 & $\begin{array}{r}0.6555^{\mathrm{a}} \\
(0.1329) \\
\end{array}$ & & & \\
\hline
\end{tabular}

$\overline{\text { Notes: }: \text { prob }<1 \% ; ~}{ }^{\mathrm{b}}$ prob $<5 \%$ 
Table 7. Significant price differences between countries

(Wald test's p-values in parenthesis)

\begin{tabular}{|c|c|c|c|c|c|c|c|c|c|c|c|c|}
\hline & Belgium & Italy & Austria & Australia & USA & France & UK & Spain & Ireland & Netherlands & Canada & Germany \\
\hline Belgium & & 0.000 & 0.000 & 0.000 & 0.000 & 0.000 & 0.000 & 0.000 & 0.000 & 0.000 & 0.000 & 0.000 \\
\hline Italy & & & 0.000 & 0.000 & 0.000 & 0.000 & 0.000 & 0.000 & 0.014 & 0.000 & 0.000 & 0.000 \\
\hline Austria & & & & 0.000 & 0.000 & 0.000 & 0.000 & 0.033 & 0.000 & 0.000 & 0.000 & 0.201 \\
\hline Australia & & & & & 0.131 & 0.000 & 0.000 & 0.000 & 0.000 & 0.000 & 0.000 & 0.000 \\
\hline USA & & & & & & 0.000 & 0.000 & 0.000 & 0.000 & 0.000 & 0.000 & 0.000 \\
\hline France & & & & & & & 0.000 & 0.000 & 0.000 & 0.000 & 0.000 & 0.000 \\
\hline UK & & & & & & & & 0.000 & 0.000 & 0.000 & 0.000 & 0.000 \\
\hline Spain & & & & & & & & & 0.000 & 0.000 & 0.000 & 0.181 \\
\hline Ireland & & & & & & & & & & 0.000 & 0.007 & 0.000 \\
\hline Netherlands & & & & & & & & & & & 0.000 & 0.000 \\
\hline Canada & & & & & & & & & & & & 0.000 \\
\hline Germany & & & & & & & & & & & & \\
\hline
\end{tabular}


Figure 1. Confidence intervals for OLS and QR for "superhost"

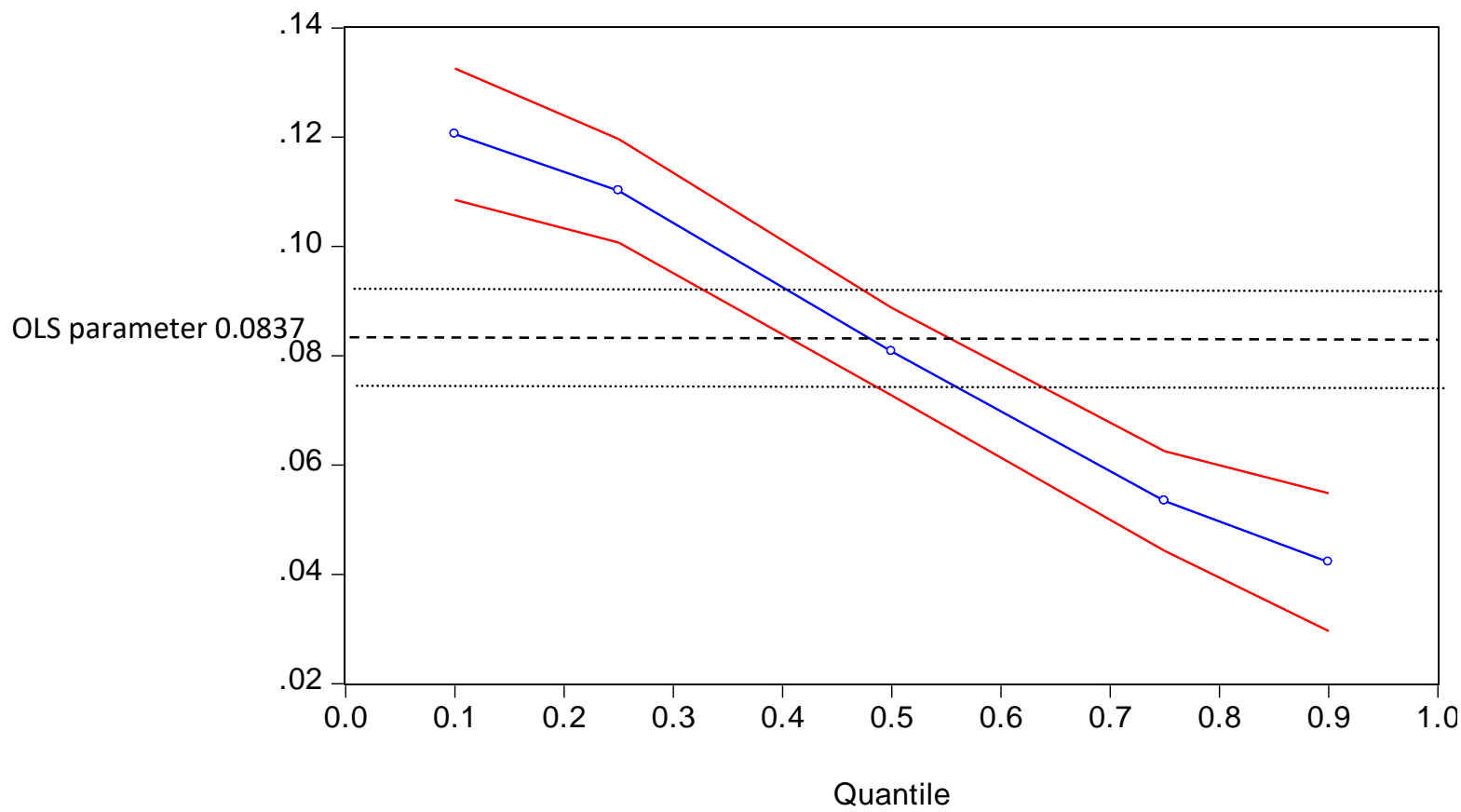


Figure 2. Confidence intervals for OLS and QR for "Host identity verified"

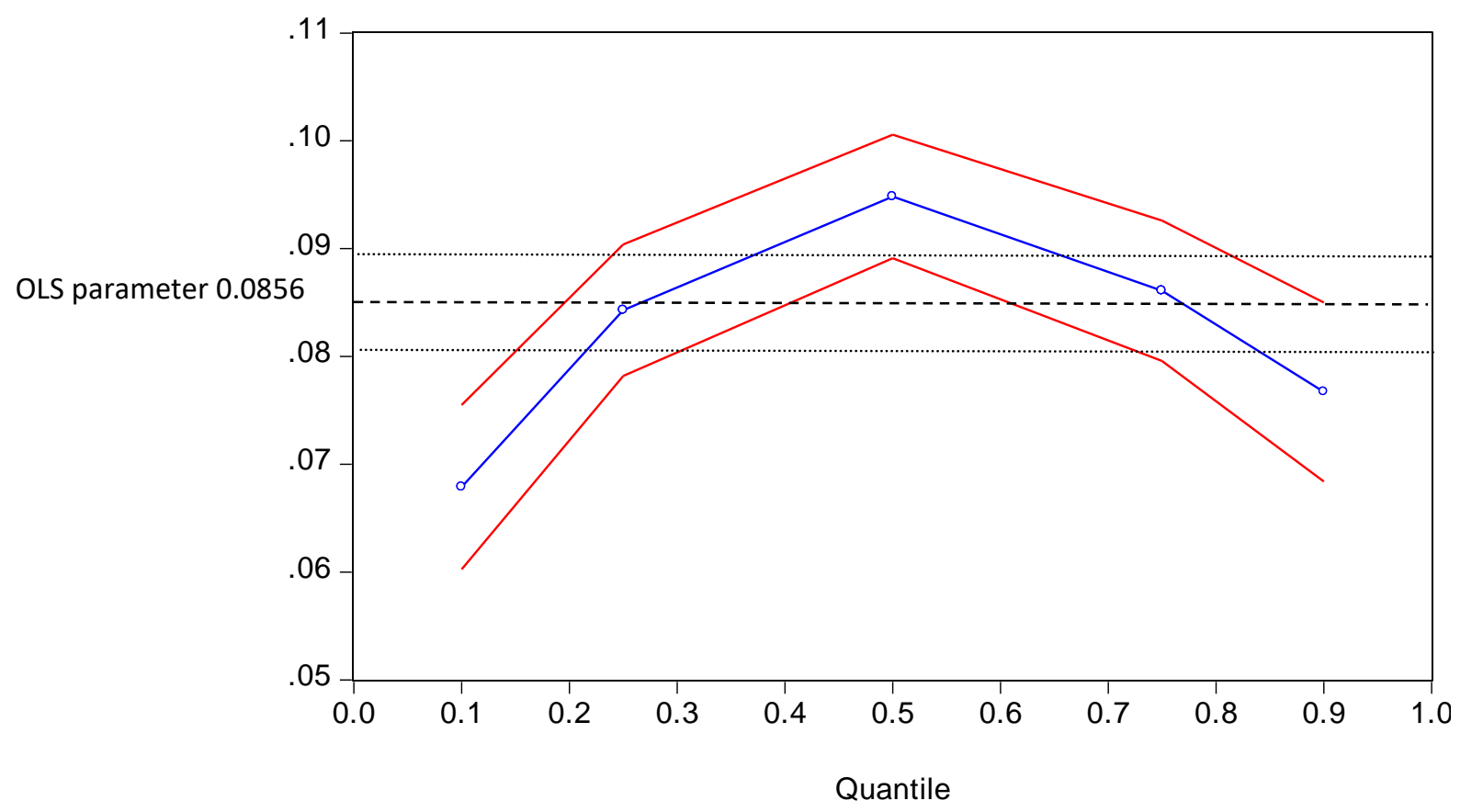


Figure 3. Effects of accommodation types

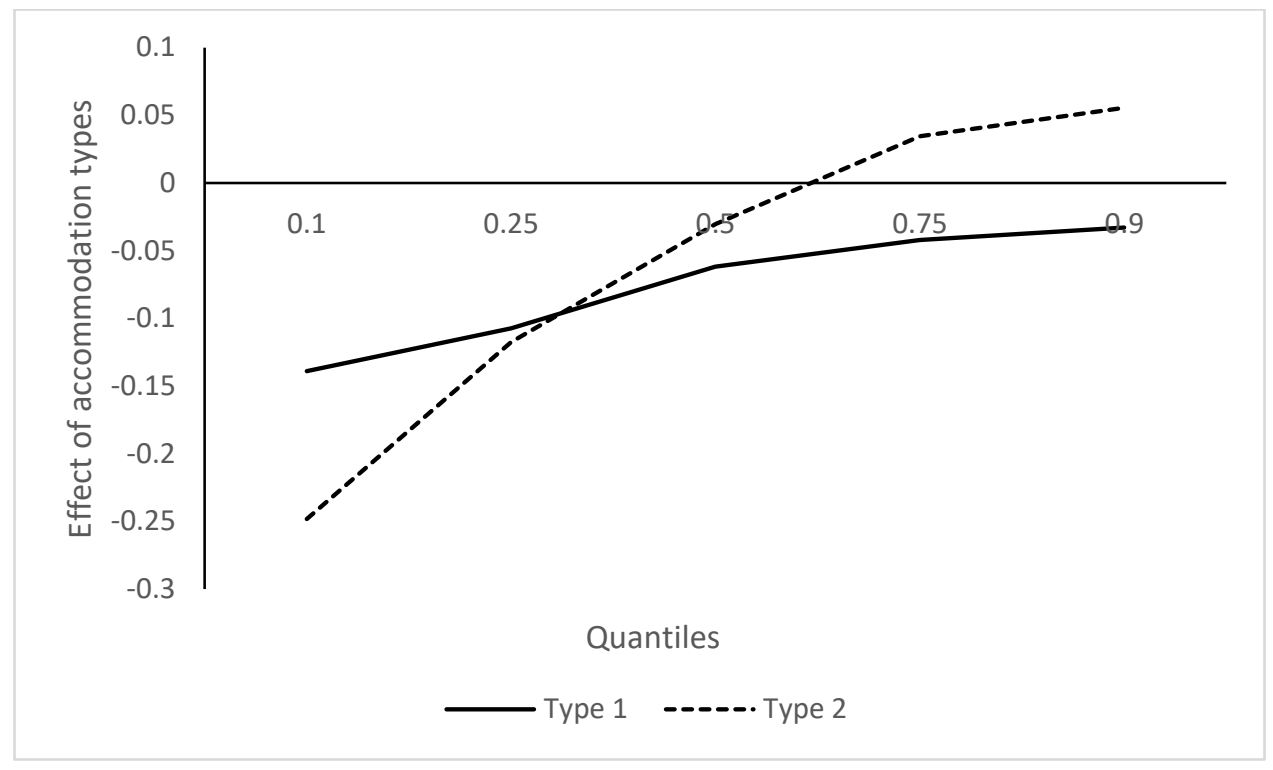

